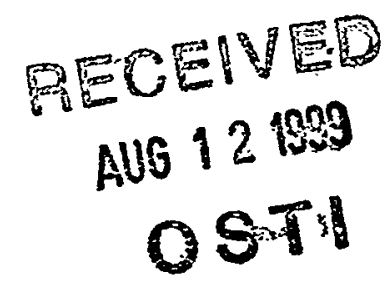

1997 Toxic Chemical Release Inventory Report for the Emergency Planning and

Community Right-to-Know Act of 1986,

Title III, Section 313

$x "$ 
Editing and Photocomposition by Lynne Atencio, Group CIC-1

An Affirmative Action/Equal Opportunity Employer

This report was prepared as an account of work sponsored by an agency of the United States Government. Neither The Regents of the University of California, the United States

Government nor any agency thercof, nor any of their employees, makes any warranty, express or intplied, or assumes any legal liability or responsibility for the accuracy, completeness, or usefulness of any information, apparatus, product, or process disclosed, or represents that its use would not infringe privalely owned rights. Reference herein to any specific commercial product, process, or service by trade name, trademark, manufacturer, or otherwise, does not necessarily constitute or imply its endorsement, recommendation, or favoring by The Regents of the University of California, the United States Government, or any agency thereof. The views and opinions of authors expressed herein do not necessarily state or reflect those of The Regents of the University of California, the United States Government, or any agency thereof. Los Alamos National Laboratory stronthly supports academic freedom and a researcher's right to publish; as an institution, however, the Laboratory does not endorse the viewpoint of a publication or guarantee its technical correctness. 


\section{DISCLAIMER}

Portions of this document may be illegible in electronic image products. Images are produced from the best available original document. 
1997 Toxic Chemical Release Inventory Report

for the Emergency Planning and

Community Right-to-Know Act of 1986,

Title III, Section 313

Heather McBride 


\section{TABLE OF CONTENTS}

Tables .$v i$

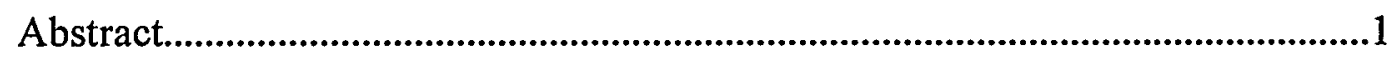

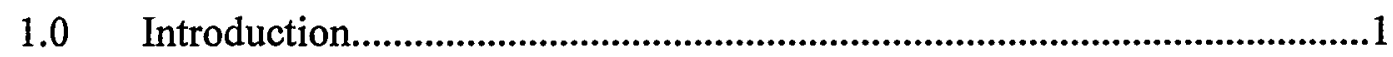

$2.0 \quad$ Facility Information and Contacts ...........................................................2

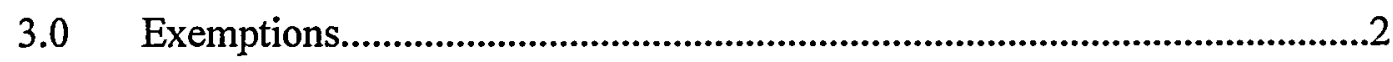

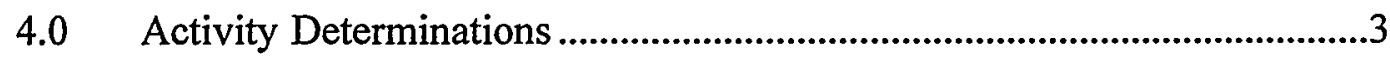

$5.0 \quad$ Production Operations...............................................................................

6.0 Toxic Chemical Analysis...............................................................................4

7.0 Toxic Chemical Requiring Form R Submittal ...............................................6

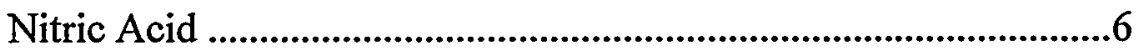

8.0 Toxic Chemicals Reviewed with No Reporting Required.............................9

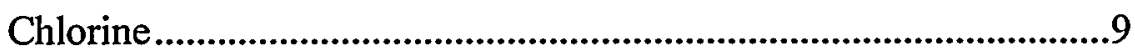

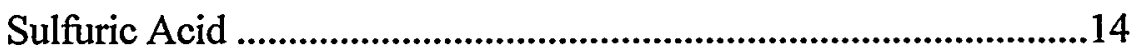

Beryllium.........................................................................................15

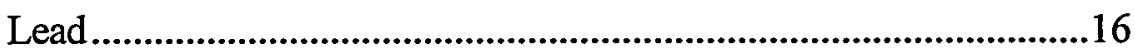

Cyanide and Nitrate Compounds.......................................................18

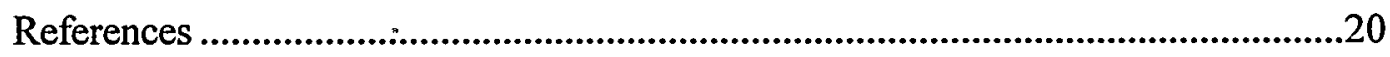

Appendix A: Toxic Chemical Purchasing and Receiving Data Analysis

Appendix B: Subcontractor Chemical Usage Data

Appendix C: Form R Reports for Nitric Acid

Appendix D: TANKS 3.1 Emission Reports for Nitric Acid

Appendix E: Toxic Chemical Use Threshold Data Summary 


\section{TABLES}

6-1 EPCRA 313 Constituents from 137 Mixtures......................................5

7-1 Controlled Emissions from Plutonium Processing .................................

7-2 Nitric Acid Operations in Plutonium Processing.................................8

8-1 Sewage Treatment Air Emissions.........................................................10

8-2 Power Plant Cooling Water Air Emissions ...........................................11

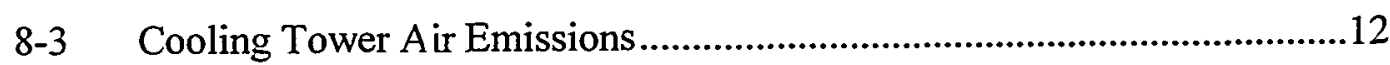

8-4 Drinking Water Treatment Air Emissions.............................................13

8-5 Drinking Water Treatment Water Releases ..............................................13

8-6 Total Water Treatment Air Emissions ..............................................13

8-7 Chlorine Threshold Determinations.................................................... 14

8-8 Lead Threshold Determination............................................................ 17

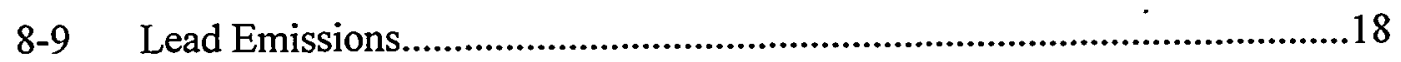

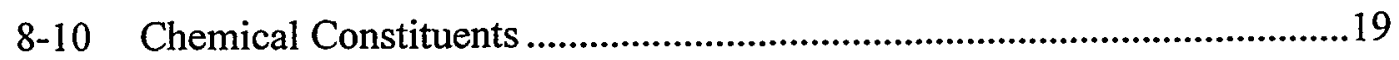

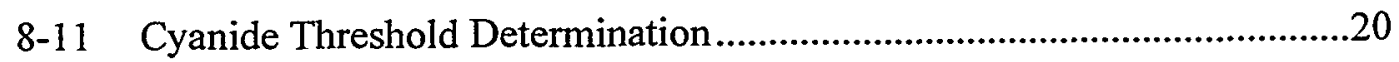




\title{
1997 Toxic Chemical Release Inventory Report \\ for the \\ Emergency Planning and \\ Community Right-to-Know Act of 1986,
}

Title III, Section 313

Heather McBride

\begin{abstract}
The Emergency Planning and Community Right-to-Know Act of 1986 (EPCRA), Title III, Section 313 [also known as the Superfund Amendment and Reauthorization Act (SARA)], as modified by Executive Order 12856, requires all federal facilities to submit an annual Toxic Chemical Release Inventory report every July for the preceding calendar year. Owners and operators of manufacturing, processing, or production facilities are required to report their toxic chemical releases to all environmental mediums (air, water, soil, etc.). At Los Alamos National Laboratory (LANL), nitric acid was the only toxic chemical used in 1997 that met the reportable threshold limit of $10,000 \mathrm{lb}$. Form $\mathrm{R}$ is the only documentation required by the Environmental Protection Agency, and it is included in the appendix of this report. This report, as requested by DOE, is provided for documentation purposes. In addition, a detailed description of the evaluation and reporting process for chemicals and processes at LANL has been included.
\end{abstract}

\subsection{INTRODUCTION}

The Emergency Planning and Community Right-to-Know Act of 1986 (EPCRA), Title II, Section 313 [also known as the Superfund Amendment and Reauthorization Act (SARA)] requires the owners and operators of certain manufacturing, processing, or production facilities that use more than a threshold amount of any listed "toxic chemicals" to annually submit a Toxic Chemical Release Inventory Reporting Form ("Form R") for those chemicals.

In addition, Executive Order 12856, dated August 3, 1993, requires that beginning in 1995, all federal facilities, regardless of their standard industrial classification code, must report their toxic chemical use and resulting releases reflecting the previous year as required by 
EPCRA 313. Under this order, Los Alamos National Laboratory (the Laboratory or LANL), which is owned by the Department of Energy (DOE), is required to report quantities of toxic chemicals used for manufacturing, processing, or production that are equal to or greater than $25,000 \mathrm{lb}$ per year and quantities of $10,000 \mathrm{lb}$ or more for toxic chemicals otherwise used. Toxic chemicals used in laboratory activities (laboratory exemption) or for certain facility maintenance activities (activity exemption) remain exempt from reporting requirements.

This report has been written to summarize the data evaluation, exemption analysis, activity determinations, threshold determinations, emissions estimates, and the reporting process. Appendix A is a list of the pure chemicals and their total amounts purchased, appendix B provides information about subcontractors' chemical usage, appendix $C$ contains copies of the Form $\mathrm{R}$ report for nitric acid, appendix $\mathrm{D}$ contains copies of nitric acid emission reports from storage tanks, and appendix $\mathrm{E}$ summarizes the toxic chemical-use threshold data.

\subsection{FACILITY INFORMATION AND CONTACTS}

LANL is located at a latitude of $350^{\circ} 49^{\prime} 51^{\prime \prime}$ and a longitude of $106^{\circ} 14^{\prime} 15^{\prime \prime}$ in Los Alamos County, New Mexico. The Laboratory is owned by the DOE and is operated by the University of California (UC). The Laboratory's Toxic Release Inventory (TRI) facility ID number is $87545 \mathrm{LSLMSLOSAL}$. The TRI facility number for the Los Alamos DOE complex is 87544 SDLSL52835. The 1997 Form R contacts are Leland Maez, UC technical contact at (505) 665-1240; George Van Tiem, UC public contact at (505) 667-6211; Herbert Plum, DOE technical contact at (505) 665-5042; and Greg Sahd, DOE public contact at (505) 665-5025.

Johnson Controls Northern New Mexico (JCNNM) is the first-tier subcontractor for the Laboratory and performs many of the Laboratory's industrial and maintenance operations, including power generation, water purification, structural maintenance, facility grounds maintenance, and motor vehicle maintenance.

\subsection{EXEMPTIONS}

Activities that are exempt from toxic chemical reporting include the following:

Laboratory Exemption

- Laboratory Activities-Listed toxic chemicals that are manufactured, processed, or otherwise used in laboratory activities at a covered facility under the direct supervision of a technically qualified individual do not have to be considered for 
threshold and release calculations. However, pilot plant scale and specialty chemical production do not qualify for this laboratory activities exemption.

Activity Exemptions

- otherwise use as a structural component of the facility;

- otherwise use in routine janitorial or facility grounds maintenance;

- personal uses by employees or other persons;

- otherwise use of products containing toxic chemicals for the purpose of maintaining motor vehicles operated by the facility; or

- otherwise use of toxic chemicals contained in intake water (used for processing or noncontact cooling) or in intake air (used either as compressed air or for combustion).

\subsection{ACTIVITY DETERMINATIONS}

Activities at the Laboratory are subject to reporting based on three different activity determinations as defined by EPCRA 313.

"Manufacture" means to produce, prepare, compound, or import a listed toxic chemical.

"Process" means the preparation of a listed section 313 chemical, after its manufacture, for distribution in commerce. Processing is usually the intentional incorporation of a section 313 chemical into a product.

"Otherwise Use" encompasses any activity involving a listed toxic chemical at a facility that does not fall under the definitions of "manufacture" or "process." A chemical that is otherwise used by a facility is not intentionally incorporated into a product distributed in commerce.

Each of these activity determinations has a corresponding threshold. The thresholds for "manufacture" and "process" are each $25,000 \mathrm{lb}$, and the threshold for "otherwise use" is $10,000 \mathrm{lb}$.

\subsection{PRODUCTION OPERATIONS}

Most of the chemicals at LANL are used in research or for industrial-type operations such as power production or water purification. Three Laboratory activities that are considered to be production operations are power production, plutonium metal processing, and drinking water treatment. 
LANL has the potential to generate electrical power for the entire LANL complex (Fig. 5-1). Power production activities involve the use of large quantities of sulfuric acid, an EPCRA 313 listed chemical. The sulfuric acid is used to maintain ionization columns that generate deionized water for steam production. In addition, chemicals are used in the cooling tower and are discussed further in section 8 .

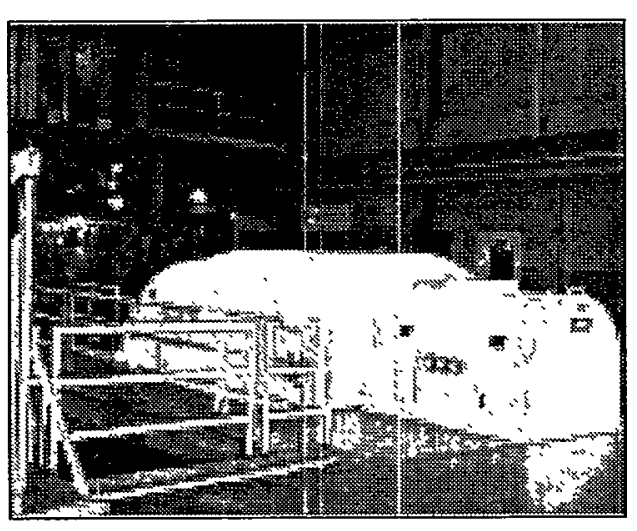

Fig. 5-1. One of several turbines at the Laboratory's power plant.
Plutonium metal processing has been considered a production-type operation in previous years for the purpose of EPCRA 313 Form R reporting, although most of the operations conducted at the plutonium processing facility involve projects related to actinide research. Nitric acid used to process plutonium metal has historically exceeded the $10,000 \mathrm{lb}$ reporting threshold.

Drinking water treatment operations involve treating or purifying water to drinking water standards. About $60 \%$ of the water that is treated by the Laboratory's first-tier subcontractor JCNNM is sold to the community for drinking water. The remaining $40 \%$

remains on Laboratory property and is used for process activities and employees' personal use.

The operations described above represent some of the production-type operations conducted at the Laboratory. These operations were chosen as a starting point for determining EPCRA 313 reporting applicability because they can potentially use large amounts of chemicals but do not qualify for the exemptions. For operations that are known to use large amounts of chemicals, the site managers or chemical users are contacted about what quantities are used and in what processes they are used. The Automated Chemical Inventory System (ACIS), procurement records, and the records from individual contractors are also examined.

\subsection{TOXIC CHEMICAL ANALYSIS}

For this 1997 EPCRA 313 report, the ACIS was used to determine which chemicals were purchased above threshold-level quantities. The ACIS contains information such as quantity, delivery location, and user data. Purchase records were used to obtain additional chemical information for chemicals that were not included in the ACIS database. This procurement information is used to determine or verify the amount of toxic chemicals brought on-site in quantities of $10,000 \mathrm{lb}$ or more. 
A recent analysis compared 1996 ACIS procurement records against wall-to-wall inventory records. This analysis indicated that the ACIS is approximately $89 \%$ accurate in capturing the Laboratory's chemical inventory.

In addition to pure chemicals [chemicals having an identifiable Chemical Abstracts Service (CAS) number], over 1,534 different chemical mixtures (totaling 23,584 lb) were evaluated. Material Safety Data Sheets (MSDSs) for 137 (totaling 20,278 lb) of the 1,534 chemical mixtures were further analyzed to determine if the mixtures contained EPCRA 313 chemical components. The remaining 1,397 chemical mixtures (totaling 3,306 lb) were not evaluated.

The table in appendix A shows the pure EPCRA 313 chemicals from ACIS, and their associated total weights, that were procured by the Laboratory in 1997. Chemicals with large total weights-for example, nitric acid and chlorine-are discussed further in sections 7.0 and 8.0 , respectively. The rest of the chemicals contribute quantities that are significantly below the most conservative threshold ( $10,000 \mathrm{lb}$ for "otherwise used") and are not discussed further.

Table 6-1 shows the quantity of EPCRA 313 chemical constituents that were present in the mixtures that were evaluated from 137 MSDSs. This table shows that the amount of toxic chemicals contained in the mixtures used at the Laboratory do not contribute significantly to the threshold value for reporting when they are added to the amount of pure chemicals purchased by the Laboratory (appendix A).

Table 6-1. EPCRA 313 Constituents from 137 Mixtures

\begin{tabular}{||c|l|c||}
\hline Total Weight (lb) & \multicolumn{1}{|c|}{ Toxic Chemical } & CAS Number \\
\hline 238.5 & chlorodifluoro-methane & 75456 \\
\hline 153 & 2-chloro-1,1,1,2-tetrafluoroethane & 2837890 \\
\hline 99.5 & dichlorofluoroethane & 1717006 \\
\hline 95.4 & methylene chloride & 75092 \\
\hline 32.5 & xylene & 1330207 \\
\hline 21 & $1,1,1-$ trichloroethane & 71556 \\
\hline 6.2 & butyl alcohol & 71363 \\
\hline 5.88 & glycol ether & 111466 \\
\hline 3.75 & phenol & 108952 \\
\hline 3.16 & o-dichlorobenzene & 95501 \\
\hline 2.9 & 1,2,4-trimethyl benzene & 95636 \\
\hline 1.35 & methyl alcohol & 67561 \\
\hline 1.12 & trichlorotrifluoroethane & 76131 \\
\hline
\end{tabular}




\section{Nitric Acid}

A total of 7,067 lb of nitric acid was received by the Laboratory and used in 1997 for exempt operations (laboratory research, soil characterization activities, etc.). An additional 29,400 lb of nitric acid acquired from large purchases was used in plutonium processing activities. This amount does not fall under the manufacturing or processing activity determination; therefore, it falls under otherwise use and it exceeds the $10,000 \mathrm{lb}$ reporting threshold. Consequently, nitric acid is reported on the Form $\mathrm{R}$.

In addition to nitric acid, the plutonium processing facility used hydrofluoric and hydrochloric acids. However, only $8 \mathrm{lb}$ of hydrofluoric acid and 2,307 lb of hydrochloric acid were used-well below the "otherwise use" reporting threshold of $10,000 \mathrm{lb}$.

The amount of nitric acid used in 1997 was approximately 30\% lower than that used in 1996 because several processes were not operational in 1997.

To better determine nitric acid emissions, LANL conducted a source test in $1988 .{ }^{1}$ During the test, processes using the most nitric acid were run at maximum operating conditions. Because the processes have not changed significantly since that test, the emission factors determined from the source test were applied to the 1997 usage quantity to calculate 1997 stack emissions. Mass balances and engineering judgment were used to estimate the emissions for several processes that used only small amounts of nitric acid and, therefore, were not tested. Nitric acid emissions from the storage tank (Fig. 7-1) were calculated with the EPA-provided software TANKS 3.1 (emissions report is located in appendix D). The emissions from the nitric acid storage tank totaled $9 \mathrm{Ib}$. Table $7-1$ shows the controlled emissions and the emission factors used for the estimates. Table 7-2 includes a description of the processes and the basis for the emissions factors.

On the Form R, numerical values are required in Part II, section 5.2, "Stack or Point Air Emissions," and in Part II, section 8.6, "Quantity Treated On-Site." The stack or point air emission estimate can be calculated by adding the total nitric acid controlled emissions from plutonium processing (from Table 7-1) to the total emissions from the storage tank (from page 5 in appendix $D$ ). This formula yields a total air emission of $720 \mathrm{lb}$.

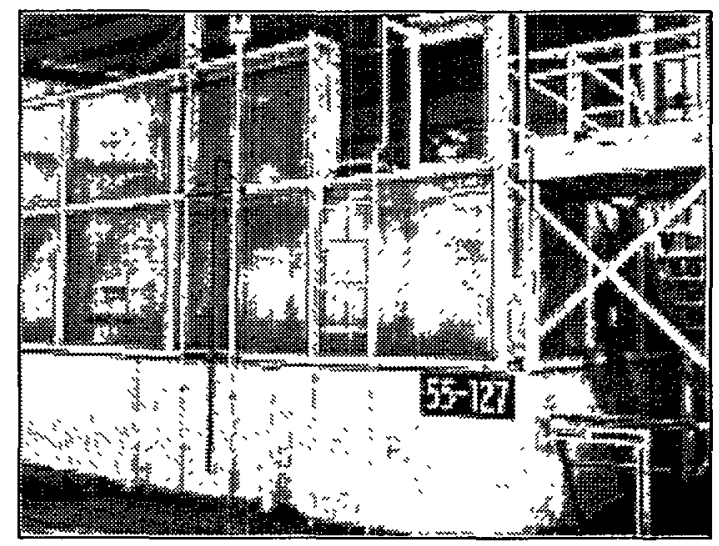

Fig. 7-1. Nitric acid storage tank. 
The quantity treated on-site is calculated by using the following mass balance:

$$
\begin{gathered}
\begin{array}{c}
\text { Quantity treated } \\
\text { on-site }
\end{array} \\
\text { Amount of } \\
\text { nitric acid used }
\end{gathered}-\begin{gathered}
\text { Amount of nitric acid } \\
\text { reacted to nitrogen oxide } \\
\text { and nitrogen dioxide }
\end{gathered}-\begin{gathered}
\text { Amount of air } \\
\text { emissions }
\end{gathered}
$$

The quantity treated on-site refers to only that quantity that is chemically converted or destroyed, according to guidance received from the EPA. Therefore, the quantity treated onsite is the total amount of liquid nitric acid waste that is neutralized.

Table 7-1. Controlled Emissions from Plutonium Rrucessing

\begin{tabular}{|c|c|c|c|c|c|c|c|}
\hline \multirow{2}{*}{ Process (Room No.) } & \multirow{2}{*}{$\begin{array}{c}\mathrm{HNO}_{3} \\
\text { (lb) }\end{array}$} & \multicolumn{3}{|c|}{$\begin{array}{l}\text { Emission Factors } \\
(\text { (lb/lb) }\end{array}$} & \multicolumn{3}{|c|}{$\begin{array}{l}\text { Controlled Emissions } \\
\text { (lb/yr) }\end{array}$} \\
\hline & & $\begin{array}{l}\text { Nitric } \\
\text { Acid } \\
\end{array}$ & $\begin{array}{c}\begin{array}{c}\text { Nitrogen } \\
\text { Oxide }\end{array} \\
\end{array}$ & $\begin{array}{c}\text { Nitrogen } \\
\text { Dioxide } \\
\end{array}$ & $\begin{array}{l}\text { Nitric } \\
\text { Acid }\end{array}$ & $\begin{array}{c}\text { Nitrogen } \\
\text { Oxide }\end{array}$ & \begin{tabular}{|c|}
$\begin{array}{c}\text { Nitrogen } \\
\text { Dioxide }\end{array}$ \\
\end{tabular} \\
\hline Waste Immobilization (401) & 274 & 0.0 & 0.001 & 0.0047 & 0.0 & 0.27 & 1.29 \\
\hline Cascade Dissolution (401) & 1270 & 0.00136 & 0.00109 & 0.003 & 1.73 & 1.38 & 3.81 \\
\hline Cascade Dissolution (420) & 8752 & 0.075 & 0.0099 & 0.095 & 656 & 86.6 & 831 \\
\hline Distillation (401) ${ }^{\mathrm{a}}$ & 14647 & 0.0016 & 0.0012 & 0.0034 & 23.4 & 17.6 & 49.8 \\
\hline Alpha Counting (116) & 77 & 0.0 & 0.015 & 0.0442 & 0.0 & 1.16 & 3.40 \\
\hline Anion Exchange (409) & 18435 & 0.0012 & 0.0 & 0.0 & 22.1 & 0.0 & 0.0 \\
\hline $\mathrm{ICP}(106)$ & 77 & 0.0 & 0.01 & 0.03 & 0.0 & 0.77 & 2.31 \\
\hline OH Cake Dissolution (409) & 456 & 0.014 & 0.0069 & 0.019 & 6.38 & 3.15 & 8.66 \\
\hline Filtrate Concentration (209) & 31 & 0.0016 & 0.0012 & 0.0034 & 0.0496 & 0.0372 & 0.105 \\
\hline Metallography (115) & 59 & 0.0099 & 0.0 & 0.0 & 0.584 & 0.0 & 0.0 \\
\hline TOTAL & 29,400 & & & & 711 & 111 & 900 \\
\hline
\end{tabular}

a Usage total does not include distillation of filtrate concentration processes, which uses recovered nitric acid from other processes. 
Table 7-2. Nitric Acid Operations in Plutonium Processing

\begin{tabular}{|c|c|c|}
\hline Process (Room) & Description & Emission Basis \\
\hline $\begin{array}{l}\text { Waste Immobilization } \\
(401)\end{array}$ & $\begin{array}{l}\text { Ammonia-containing chemical waste is stored in a glovebox for a few days prior to its neutralization } \\
\text { and solidification with cement in open cans. Nitric acid is used to clean the glovebox and is left in the } \\
\text { cement-containing cans to oxidize overnight. The cans are loaded in lead-lined drums and shipped to } \\
\text { TA-54 for waste disposal. }\end{array}$ & $\begin{array}{l}99.14 \% \text { of nitric acid remains in } \\
\text { product. The difference converts to } \\
\text { nitrogen oxide and nitrogen dioxide } \\
\text { (Ref. 1). }\end{array}$ \\
\hline Cascade Dissolution (401) & Plutonium oxide dissolved in $15.6 \mathrm{M}$ of nitric acid with calciun difluoride at $96^{\circ} \mathrm{C}$. & Use 1988 emission factors. \\
\hline Cascade Dissolution (420) & Plutonium dioxide and magnesium oxide dissolved in $10 \mathrm{M}$ of nitric acid at $100^{\circ} \mathrm{C}$. & Use 1988 emission factors. \\
\hline Distillation (401) & $\begin{array}{l}\text { Waste nitric acid, ammonia, and water are condensed before disposal. The distillate is condensed in a } \\
\text { one-shell, two-pass condenser and sent to TA-50. Bottoms are sent to TA-54 for disposal. }\end{array}$ & Use 1988 emission factors. \\
\hline Alpha Counting (116) & Radioactive samples are dissolved in nitric acid and heated to $122^{\circ} \mathrm{C}$ during analytical processing. & $\begin{array}{l}87.59 \% \text { of nitric acid remains in } \\
\text { product or waste. The difference } \\
\text { converts to nitrogen oxide and } \\
\text { nitrogen dioxide (Ref. 1). }\end{array}$ \\
\hline Anion Exchange (409) & $\begin{array}{l}\text { Plutonium solution is passed through a resin bed after the } \mathrm{pH} \text { and concentration is adjusted to } 7 \mathrm{M} \\
\text { using a 15.6-M solution of nitric acid. }\end{array}$ & $\begin{array}{l}\text { Assume the volume of nitric acid } \\
\text { used displaces an equal volume of air } \\
\text { saturated with nitric acid. }\end{array}$ \\
\hline $\begin{array}{l}\text { Inductively Coupled } \\
\text { Plasma (ICP) Atomic } \\
\text { Emission Spectroscopy } \\
\text { (106) }\end{array}$ & $\begin{array}{l}\text { An 8-M nitric acid solution is used to dilute plutonium solution samples and as a blank standard for } \\
\text { ICP analysis. }\end{array}$ & $\begin{array}{l}\text { Lab personnel estimate } 4 \% \text { of the } \\
\text { nitric acid remains in the plasma and } \\
\text { is emitted as nitrogen oxides } \\
\text { (Ref. 1). }\end{array}$ \\
\hline $\begin{array}{l}\text { OH Cake Dissolution } \\
(409)\end{array}$ & $\begin{array}{l}\text { Plutonium hydroxide precipitates from various plutonium recovery processes are filtered, concentrated, } \\
\text { and redissolved. }\end{array}$ & $\begin{array}{l}\text { Use "Scrap Dissolution and } \\
\text { Plutonium Oxide Dissolution (209)" } \\
\text { emission factors (1988). }\end{array}$ \\
\hline $\begin{array}{l}\text { Filtrate Concentration } \\
\text { (209) }\end{array}$ & $\begin{array}{l}\text { Plutonium hydroxide precipitates from various plutonium recovery processes are filtered, concentrated, } \\
\text { and redissolved. }\end{array}$ & $\begin{array}{l}\text { Use "Distillation (401)" emission } \\
\text { factors (1988). }\end{array}$ \\
\hline Metallography (115) & Cut plutonium samples are placed in a nitric acid etching solution to clean the cut surfaces. & $\begin{array}{l}\text { Assume } 1 \% \text { evaporates, based on } \\
\text { engineering judgement. }\end{array}$ \\
\hline
\end{tabular}




\subsection{TOXIC CHEMICALS REVIEWED WITH NO REPORTING REQUIRED}

\section{Chlorine}

The bulk of the chlorine at the Laboratory is used in water treatment (i.e., sewage, power plant process water, cooling tower water, and drinking water). In addition to the chlorine used to treat water, $18 \mathrm{lb}$ were used in laboratory processes other than water treatment. The chemicals used in water treatment include chlorine gas, sodium chloride, and chorinebromine tablets. Each water treatment application is described below, along with its appropriate activity determination.

\section{$\underline{\text { Sewage Treatment }}$}

The Sanitary Waste Systems Consolidations (SWSC) plant treated 108.401 million gallons of sewage in 1997 in the SWSC plant's new mixed oxide (MIOX) treatment system (Fig. 8-1).

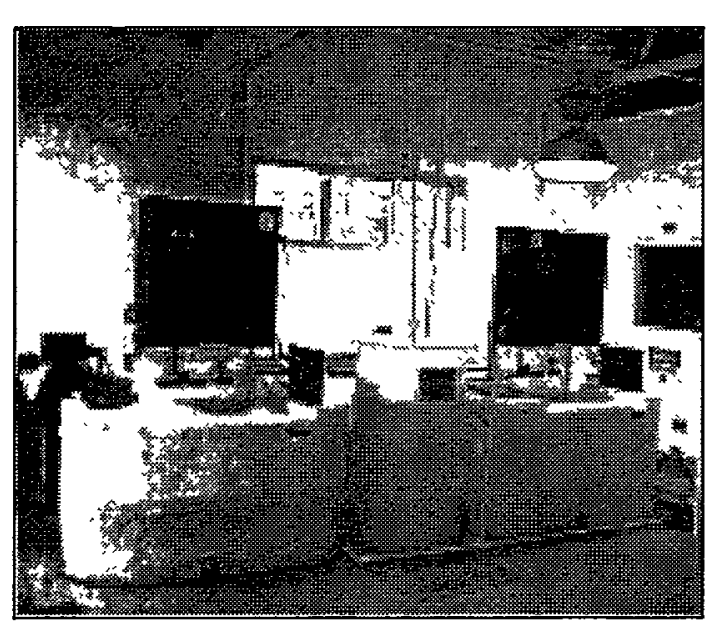

Fig. 8-1. New MIOX system for treating sanitary waste.
A brine solution made from salt (sodium chloride) is passed through an electrolytic cell where it is converted into a strong oxidizing solution that is composed of hypochlorous acid, chlorine, chlorine dioxide, and ozone. Of these four chemicals, chlorine, chlorine dioxide, and ozone are listed as toxic chemicals under EPCRA 313. Although these mixed oxidants are generally $20 \%$ to $40 \%$ more effective than chlorine gas treatment, the MIOX system is estimated to be about $5 \%$ as efficient for treating water compared to chlorine treatment [i.e., procurement records indicate that approximately $95 \%$ more salt

(by weight) was required to provide the same treatment effect as was provided the previous year with chlorine gas].

Salt, a compound of sodium and chloride, is not reported on a Form $\mathrm{R}$ because it does not fall into any of the regulated compound categories, it is not a chemical mixture, and its CAS number, 7647-14-5, is not included with the listed toxic chemicals. However, the quantities of chlorine, chlorine dioxide, and ozone that are produced as byproducts of the process apply to the threshold for "manufacture." The estimated quantities of these oxidants were calculated from manufacturer's data and represent the maximum quantities that could be produced by the full capacity operation of the three cells in the SWSC plant's treatment system. Up to $10,950 \mathrm{lb}$ of chlorine, $228 \mathrm{lb}$ of chlorine dioxide, and 
$228 \mathrm{lb}$ of ozone could be produced. Because these chemicals are produced in quantities less than the threshold of $25,000 \mathrm{lb}$, they are not discussed further.

In addition to the byproducts generated from the MIOX, additional air emissions are generated from the treatment of wastewater with the MIOX system. Chloroform emissions were calculated using the most conservative emission factor available. The chloroform air emissions are shown in Table 8-1. Data was not available from the MIOX manufacturer to estimate chlorine, chlorine dioxide, and ozone emissions. There was no chlorine released in water because the water is dechlorinated before its release from the SWSC plant.

Table 8-1. Sewage Treatment Air Emissions

\begin{tabular}{|l|c|c|c||}
\hline \hline Pollutant & Emission Factor & Reference & Emissions (lb/yr) \\
\hline Chloroform & $1.68 \times 10^{-7} \mathrm{lb} / 1000$ gal. & EPA-450/2-90-011 (Ref. 2) & 12.7 \\
\hline Chlorine & $\mathrm{NA}$ & $\mathrm{NA}$ & Undetermined \\
\hline
\end{tabular}

\section{Power Plant Cooling Water Treatment}

The power plant (Fig. 8-2) treated 18.6 million gallons of cooling water in 1997 with approximately $2,750 \mathrm{lb}$ of chlorine-bromine tablets (Formula 314-T).

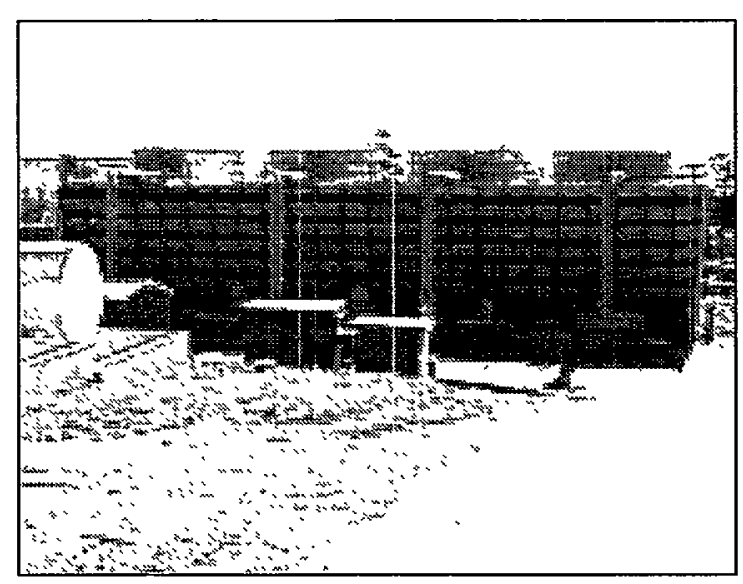

Fig. 8-2. Power plant cooling tower.
The Formula 314-T tablets are considered to be a compound and are, therefore, not subject to EPCRA 313 reporting requirements because they do not fall into any of the regulated compound categories, they are not a mixture, and their CAS number, 126-06-7, is not included in the listed toxic chemicals. However, the quantities of chlorine and bromine produced as byproducts of the process apply to the threshold for "manufacture." According to the manufacturer, small amounts of chlorine can be produced from the treated water by exposure to ultraviolet light or ozone. 
The chlorine produced, however, would be less than $0.1 \%$ of the total tablets added. Therefore, less than $2.75 \mathrm{lb}$ of chlorine $\left(\mathrm{as}_{2}\right.$ ) would be produced from the use of the tablets. The amount of bromine ( $\mathrm{as} \mathrm{Br}_{2}$ ) that would be produced is significantly less than $0.1 \%$. Other byproducts-hypochlorous acid (7790-92-3), hypobromous acid (13517-11-8), and hypochlorite (14380-61-1) —are not regulated under EPCRA 313.

Air emissions are calculated and shown in Table 8-2. Bromoform, chlorine, and chloroform are all released as air pollutants from cooling water treatment. Water releases are not considered because the water is chemically dechlorinated before it is released from the power plant.

Table 8-2. Power Plant Cooling Water Air Emissions

\begin{tabular}{|l|c|c|c||}
\hline Pollutant & \multicolumn{1}{|c|}{ Emission Factor } & Reference & $\begin{array}{c}\text { Emissions } \\
(\mathbf{l b} / \mathbf{y r})\end{array}$ \\
\hline Chloroform & $6.25 \mathrm{lb} / 10^{6}$ gal. of cooling water & EPA-450/2-90-011(Ref. 2) & 116 \\
\hline Chlorine & $0.02 \mathrm{lb} / \mathrm{lb}$ of chlorine in water & Ref. 3 & 1.0 \\
\hline Bromine & $0.02 \mathrm{lb} / \mathrm{lb}$ of bromine in water ${ }^{\mathrm{a}}$ & Ref. 3 & 1.3 \\
\hline Bromoform & $2.95 \mathrm{lb} / 10^{6}$ gal. of cooling water & $\begin{array}{c}\text { Engineering calculations } \\
\text { based on molecular weight }\end{array}$ & 54.8 \\
\hline
\end{tabular}

"Assumed the bromine residual is the same as the chlorine residual.

Cooling Tower Water Treatment

According to procurement records, $2881.8 \mathrm{lb}$ of Formula 314-T tablets were used to treat the cooling tower water at TA-53 (Fig. 8-3). If the same analysis is used for the cooling tower water treatment as was used above for the power plant cooling water treatment, less than $2.88 \mathrm{lb}$ of $\mathrm{Cl}_{2}$ will be produced from the use of the tablets. This quantity is also applied to the "manufacture" threshold.

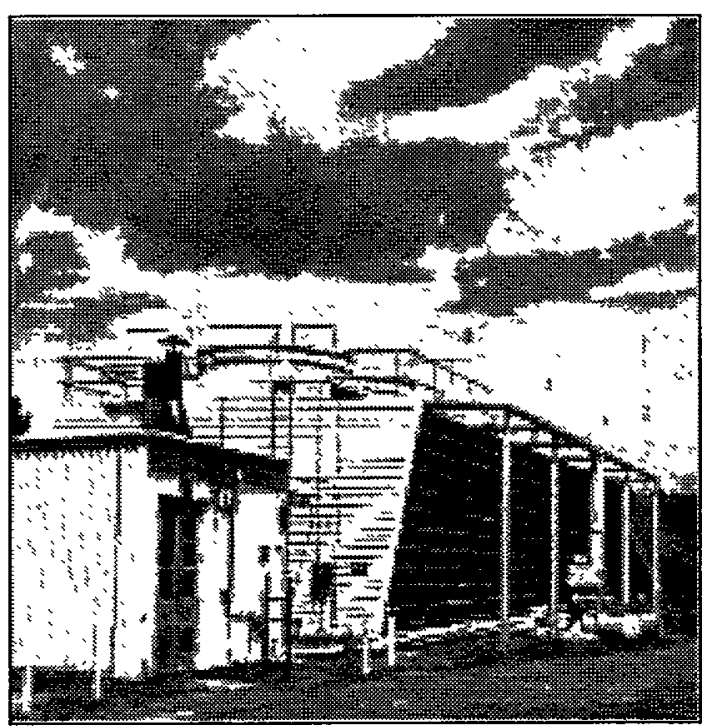

Fig. 8-3. Cooling tower at TA-53. 
Air emissions are calculated and shown in Table 8-3. Bromoform, chlorine, and chloroform are all released as air pollutants in this process. Water releases are not considered because water is dechlorinated before release.

Table 8-3. Cooling Tower Air Emissions

\begin{tabular}{||l|c|c|c||}
\hline Pollutant & $\begin{array}{c}\text { Emission Factor } \\
\text { Chloroform }\end{array}$ & Reference & $\begin{array}{c}\text { Emissions } \\
\text { (lb/yr) }\end{array}$ \\
\hline Chlorine & $0.25 \mathrm{lb} / 10^{6}$ gal. of cooling water & EPA-450/2-90-011 (Ref. 2) & 156 \\
\hline Bromine & $0.02 \mathrm{lb} / \mathrm{lb}$ of bromine in water ${ }^{\mathrm{a}}$ & Ref. 3 & 1.4 \\
\hline Bromoform & $2.95 \mathrm{lb} / 10^{6}$ gal. of cooling water & $\begin{array}{c}\text { Engineering calculations } \\
\text { based on molecular weight }\end{array}$ & 73.7 \\
\hline
\end{tabular}

${ }^{2}$ Assumed the bromine residual is the same as the chlorine residual.

\section{Drinking Water Treatment}

Approximately 1.389 billion gallons of drinking water were treated in 1997 using chlorine gas (Fig. 8-4). Los Alamos County purchased 0.827 billion gallons of the water $(60 \%$ of the quantity treated) for community use as potable water. The total amount of chlorine gas used to treat the water was estimated to be $11,500 \mathrm{lb}$. This estimate is based on the ratio of chlorine used to water treated in 1996.

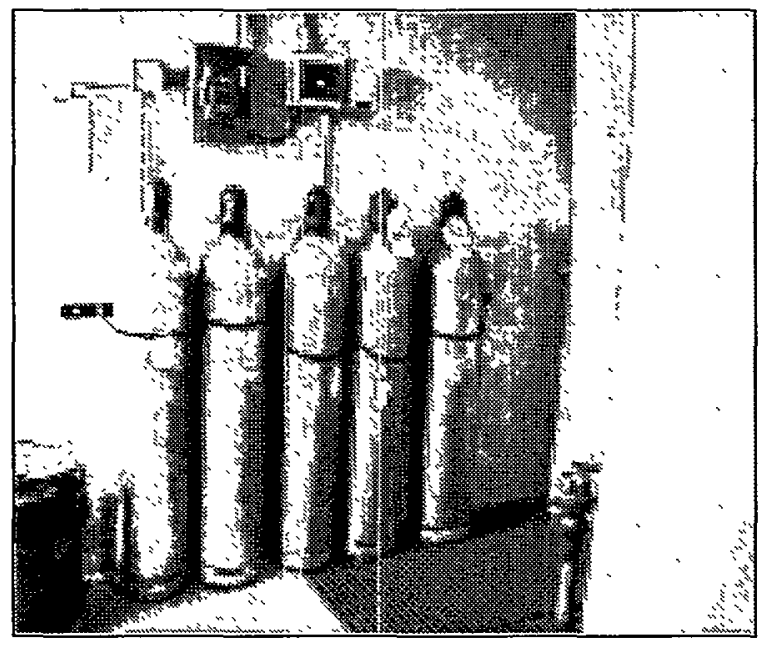

Fig. 8-4. Chlorine gas cylinders.
The use of $11,500 \mathrm{lb}$ of chlorine is applied to two different thresholds. The chlorine in the drinking water that is sold to the community falls under "the intentional incorporation of a listed toxic chemical into a product for distribution to commerce," so by definition, $60 \%$ of the chlorine used in drinking water treatment was "processed." The remaining $40 \%$ of the chlorine in the water that remained for use at LANL was applied to the threshold for "otherwise used" because it does not fall under either the definition for "manufacture" or "process." 
Air and water emissions from drinking water treatment are shown in Tables 8-4 and 8-5. Table 8-6 shows the total air emissions for all processes. Chloroform is the only pollutant released from the process into the air, and the residual chlorine is left in the water to prevent bacteria from growing during transport to its final location.

Table 8-4. Drinking Water Treatment Air Emissions

\begin{tabular}{||l|c|c|c||}
\hline Pollutant & Emission Factor & Reference & Emissions (lb/yr) \\
\hline \hline Chloroform & $3.42 \times 10^{-4} \mathrm{lb} / 1000$ gal. & EPA-450/2-90-011 (Ref. 3) & 475 \\
\hline
\end{tabular}

Table 8-5. Drinking Water Treatment Water Releases

\begin{tabular}{|l|c|c|c|}
\hline Pollutant & Emission Factor & Reference & Emissions (lb/yr) \\
\hline $\begin{array}{l}\text { Residual Chlorine } \\
\text { Released }\end{array}$ & $0.2 \mathrm{mg} / \mathrm{L}$ & Operating Data & 1570 \\
\hline
\end{tabular}

Table 8-6. Total Water Treatment Air Emissions

\begin{tabular}{|c|c|c|}
\hline \multirow{2}{*}{ Treatment Type } & \multicolumn{2}{|c|}{ Air Emissions (lb/yr) } \\
\hline & Chloroform & Chlorine \\
\hline Wastewater & 12.7 & Undetermined \\
\hline Power Plant Cooling & 116 & 1.0 \\
\hline Cooling Tower & 156 & 1.4 \\
\hline Drinking & 475 & - \\
\hline TOTALS & 759.7 & 2.4 \\
\hline
\end{tabular}


Table 8-7 reviews the threshold determinations for chlorine. Chemicals such as chloroform and bromine were not subjected to threshold determination because their quantities did not come close to the most conservative threshold of $10,000 \mathrm{lb}$. No reporting thresholds were exceeded; therefore, no reporting for chlorine was required.

Table 8-7. Chlorine Threshold Determinations

\begin{tabular}{|l|c|c|c|c||}
\hline \multirow{2}{*}{ Activity } & Threshold (lb) & $\begin{array}{c}\text { Chlorine } \\
\text { Usage (lb) }\end{array}$ & Treatment & $\begin{array}{c}\text { Total Chlorine } \\
\text { Usage (lib) }\end{array}$ \\
\hline Otherwise Used & 10,000 & 4,600 & Drinking Water & \multirow{2}{*}{4,618} \\
\cline { 3 - 4 } & \multirow{2}{*}{ Manufacture } & 18 & NA & \multirow{2}{*}{10,956} \\
\cline { 3 - 4 } & & 10,950 & Sewage & \multirow{2}{*}{6,900} \\
\hline
\end{tabular}

\section{Sulfuric Acid}

In 1995 and 1996, LANL did not report sulfuric acid because the EPCRA 313 reporting guidelines stated sulfuric acid must be reported "only if it is an aerosol." In 1997, the EPA provided a revision and new guidance on the reporting of sulfuric acid aerosols. ${ }^{4}$ The guidance document for the reporting of aerosols now states:

The amounts of acid aerosols generated in storage tanks are to be applied towards the 'manufacture' threshold for sulfuric acid aerosols. The amount of acid aerosol to be applied towards the 'manufacture' threshold is the average amount that existed in the atmosphere above the acid solution during the year.

The EPA also provided guidance on estimating sulfuric acid aerosol emissions from the combustion of fuel oil. ${ }^{4}$ It states:

All sulfuric acid produced within the stack, including the gas not just the mist, falls under the EPCRA section 313 definition of a sulfuric acid aerosol .... Sulfuric acid aerosols are produced during fuel oil combustion from the oxidation of sulfur contained in the fuel. 
Aerosol Tank Emissions

Estimated sulfuric acid tank emissions are based on tank size (4,500 gal.; Fig. 8-5.) and the number of volume turnovers per year (4). According to the EPA-approved TANKS 3.1 program, no emissions were generated. However, if conservative estimates based on vapor pressure, transport line volumes, and tank air space volumes are used, approximately $0.02 \mathrm{lb}$ was emitted.

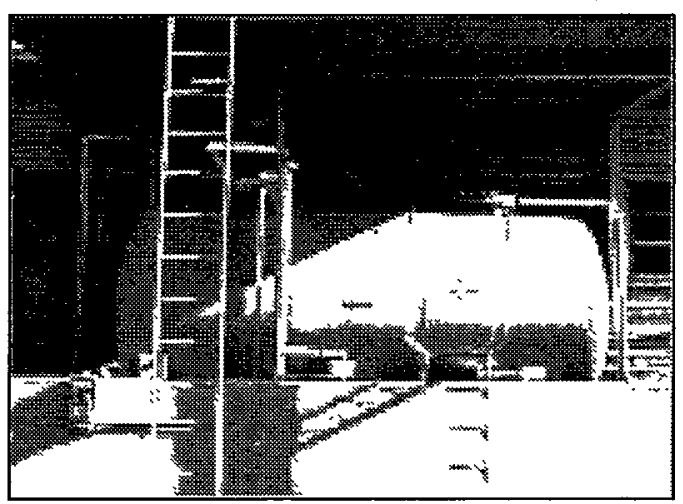

Fig. 8-5. Sulfuric acid tank.

\section{Combustion Byproducts}

Industrial-type sources (boilers, generators, etc.) of combustion byproducts at the Laboratory operate primarily on natural gas, although in one instance, fuel oil is available as backup. In 1997, the Laboratory's industrial sources were fueled exclusively with natural gas. The EPA guidance does not discuss or provide emission factors for sulfuric acid aerosol emissions from the combustion of natural gas. However, according to the Laboratory's emissions inventory, $572 \mathrm{lb}$ of sulfur oxides were released into the air from the combustion of natural gas by industrial sources at the Laboratory. For this air emissions estimate, it was assumed that natural gas contains a maximum of $0.1 \%$ sulfur. If it is assumed that the sulfur oxide emissions were sulfuric acid aerosols "manufactured" as a byproduct of fuel consumption, then $572 \mathrm{lb}$ were generated. Therefore, the total sulfuric acid aerosol emissions generated from tank off-gassing and the combustion of natural gas was $572.02 \mathrm{lb}$ and was below reporting requirements.

\section{Beryllium}

The Laboratory processed approximately $6,000 \mathrm{lb}$ of beryllium. The reporting threshold for "processing" under EPCRA 313 is $25,000 \mathrm{lb}$; therefore, it was below reporting requirements. 


\section{Lead}

\section{Decontamination of Lead Shielding}

The Laboratory decontaminated $40,000 \mathrm{lb}$ of radioactively contaminated lead shielding (Fig. 8-6). This treatment of lead qualifies for an "article exemption" on the following basis: 6

... it is formed to a specific shape or design during manufacture, that has end use functions dependent in whole or in part upon its shape or design during end use, and that do not release a toxic chemical under normal circumstances of processing or otherwise use of the item at the facility.

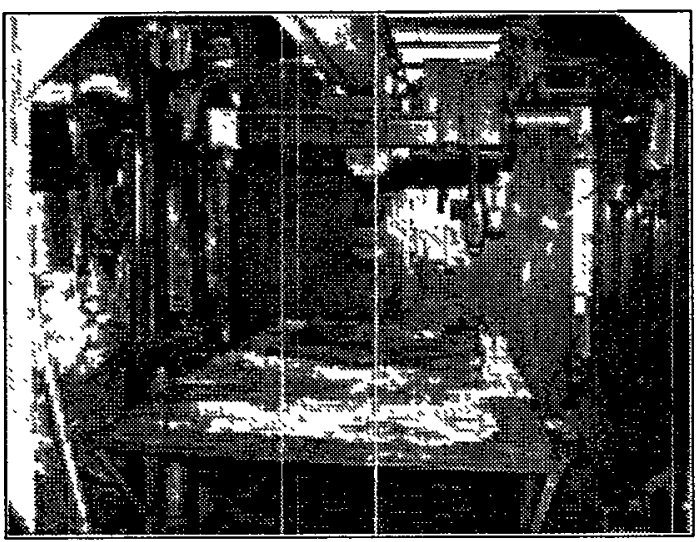

Note: The decontamination of the lead removes only the radiouctive contamination and does not change the form of the lead.

Fig. 8-6. Lead decontamination site.

There were no emissions of lead into the air since decontamination is a wet operation. The total estimated release of lead to waste is $6 \mathrm{~g}(0.013 \mathrm{lb})$, well below the $0.5 \mathrm{lb}$ "article exemption" release allowance. Form $\mathrm{R}$ instructions ${ }^{6}$ state:

EPA will allow this release to be rounded to zero, and the manufactured items remain exempt as articles.

\section{Lead Shot at the Firing Range}

Approximately 5,000 lb of lead contained in ammunition was shot at the firing range. This amount was applied to the "otherwise used" threshold of 10,000 lb. 


\section{Lead Melting}

Approximately 5,100 lb of lead was melted and formed into specific shapes for glove box and exposure shielding. Lead melting as an activity is applied to the "process" threshold, based on the guidance provided by the EPA to DOE facilities in the Department of Energy Toxic Chemical Release Inventory Reporting "Qs \& As. " Questions 34 and 37 apply to the lead-melting activities and the appropriate threshold determination. The questions and answers read as follows:

34. Lead shielding was used in the transportation of nuclear warheads. The lead shields are being recycled into containers for radioactive waste storage. Would the lead from the shields be exempt from TRI reporting under the article exemption?

No. Melting and reforming the lead shields to form storage containers would constitute manufacturing of an article, which negates the article exemption for the lead shield. Because the lead is intentionally incorporated into the radioactive waste storage containers, the lead is processed and subject to the $25,000 \mathrm{lb}$. threshold.

37. What is the difference between "process" and "otherwise use"?

"Process" implies incorporation; the chemical added is intended to become part of a product further distributed. "Otherwise use" implies non-incorporation; the chemical is not intended to become part of a product (e.g., use of toxic chemicals in the remediation of wastes is an "otherwise use" activity).

\section{Lead Procurement}

Approximately $11.18 \mathrm{lb}$ of lead was procured, according to the ACIS database. This amount of lead was applied to the "otherwise used" threshold determination. The reporting threshold for "otherwise used" under EPCRA 313 is 10,000 lb.

The thresholds for the different activity determinations involving lead are listed in Table 8-8. A comparison to the threshold determinations reveals that reporting is not required.

Table 8-8. Lead Threshold Determination

\begin{tabular}{|l|c|c|c|}
\hline Usage & Activity & Threshold (lb) & Lead (lb) \\
\hline Decontamination & Article Exemption & NA & 40,000 \\
\hline Firing Range & Otherwise Used & 10,000 & 5,011 \\
\hline $\begin{array}{l}\text { Miscellaneous Lab } \\
\text { Activities }\end{array}$ & Otherwise Used & 10,000 & 11 \\
\hline Melting & Process & 25,000 & 5,100 \\
\hline
\end{tabular}


Lead emissions for each of the three Laboratory uses are shown in Table 8-9.

Table 8-9. Lead Emissions

\begin{tabular}{|l|c|c|c||}
\hline Lead Usage & Emission Factor & Emissions (lb/yr) & Emission Type \\
\hline Decontamination & Engineering Calculation $^{\mathrm{a}}$ & 0.013 & Solid/Water \\
\hline Firing Range & $2 \times 10^{-5} \mathrm{lb} /$ cartridge $^{\mathrm{b}}$ & 14.15 & Air \\
\hline Melting & $1.5 \mathrm{lb} /$ ton (Ref. 8) & 3.83 & Air \\
\hline
\end{tabular}

${ }^{\mathrm{a}}$ This calculation was performed by Leland Maez and was based on process information given by the user, Myrna Romero (5-2069) at CST-7.

b All ammunition was standardized to cartridges. In the event specific conversion data was not available, the worst case conversion was assumed.

\section{Cyanide and Nitrate Compounds}

\section{Explosives}

Explosives were evaluated because many contain nitrates and/or cyanides that are regulated by EPCRA 313. Explosives data from project operations journals were used to determine the types and amounts of explosives detonated and burned at the Laboratory because explosives are not captured in the ACIS database.

\section{$\underline{\text { Nitrates }}$}

Nitrate compounds are reportable only when in aqueous solutions, according to the EPCRA 313, Toxic Chemical Release Inventory instructions: ${ }^{6}$

Nitrate compounds (water dissociable; reportable only when in aqueous solution)...

The nitrate components that are part of or produced from the Laboratory's explosives activities are not in aqueous solutions.

According to procurement data, additional nitrate compounds used at the Laboratory totaled $1,108 \mathrm{lb}$. This total was applied to the "otherwise used" threshold determination for nitrate compounds. The reporting threshold for "otherwise used" is $10,000 \mathrm{lb}$; therefore, reporting is not required. 


\section{Cyanides}

Cyanide compounds at the Laboratory were investigated according to EPCRA 313 guidance for both "otherwise used" and "manufactured" thresholds. The compounds would be classified as "otherwise used" if they were brought on-site and already contained cyanides as a chemical component of the explosives. However, a review of the chemicals contained in the explosives revealed that they do not contain cyanide compounds as defined by the EPCRA 313 instructions: ${ }^{6}$

. Cyanide Compounds, $X^{+} C N^{-}$where $X=H^{+}$or any other group where a formal dissociation may occur. For example $\mathrm{KCN}$ or $\mathrm{Ca}(\mathrm{CN})_{2}$.

The chemical constituents reviewed are shown in Table 8-10.

Table 8-10. Chemical Constituents

\begin{tabular}{|l||}
\hline Chemical Constituent \\
\hline Hexahydro-1,3,5-trinitro-1,3,5-triazine \\
\hline Octahydro-1,3,5,7-tetranitro-1,3,5,7-tetrazocine \\
\hline Polyurethane solution system \\
\hline Bis(2,2-dinitropropyl)acetal/bis(2,2-dinitropropyl) formal (plasticizer) \\
\hline 2-Methyl-1,3,5-trinitrobenzene \\
\hline Barium nitrate \\
\hline 1,1-(1,2-Ethenediyl) bis-(2,4,6-trinitrobenzene) \\
\hline 2,2-Bis[(nitroxy) methyl]-1,3-propanediol, dinitrate \\
\hline 2,4,6-Trinitro-1,3,5-benzenetriamine \\
\hline N-methyl-N,2,4,6-tetranitrobenzenamine \\
\hline
\end{tabular}

Also classified under the threshold determination of "otherwise used" would be the cyanide compounds used for other "laboratory activities." Approximately $65 \mathrm{lb}$ of cyanides were used for other activities and were evaluated against the "otherwise used" reporting threshold of $10,000 \mathrm{lb}$.

The 25,000 lb "manufacture" threshold for reporting was applied to all cyanides produced from explosive activities. Approximately $219 \mathrm{lb}$ of cyanides were "manufactured" from 15,070 lb of explosives; therefore, reporting is not required (Table 8-11). 
Table 8-11. Cyanide Threshold Determination

\begin{tabular}{|l|c|c|c|}
\hline Activity & Threshold (lb) & Cyanide (ib) & Usage \\
\hline Manufactured & 25,000 & 219 & Explosives \\
\hline Otherwise Used & 10,000 & 65 & Laboratory Activities \\
\hline
\end{tabular}

\section{REFERENCES}

1. PEI Associates, "Process Emission Rates, Plutonium Processing Facility, Area 400 Ventilation Exhaust, Technical Area 55," PN 3003-26-7 (February 1989).

2. U.S. Environmental Protection Agency, "Toxic Air Pollutant Emission Factors-A Compilation for Selected Air Toxic Compounds and Sources, Second Edition," EPA450/2-90-011 (1990).

3. California Air Resources Board, "Cooling Tower Supplemental Instructions, Emission Inventory Criteria and Guidelines Regulation," June 1, 1989.

4. U.S. Environmental Protection Agency, "Guidance for Reporting Sulfuric Acid (Acid Aerosols Including Mists, Vapors, Gas, Fog, and Other Airborne Forms of Any Particle Size)," in "EPCRA, Section 313," EPA-745-R-97-007 (1997).

5. "Emissions Inventory Report Summary," Los Alamos National Laboratory report LA-13528-SR (January 1999).

6. U.S. Environmental Protection Agency, "Toxic Chemical Release Inventory Reporting Form R and Instructions," Revised 1997, EPA 745-K-98-001, p. 9.

7. Department of Energy, "Toxic Chemical Release Inventory Reporting 'Qs \& As," DOE/EH-0374 (March 1994).

8. U.S. Environmental Protection Agency, "Compilation of Air Pollutant Emission Factors (AP-42), Fifth Edition," [Air CHIEF CD-ROM], (1995). 


\section{APPENDIX A \\ TOXIC CHEMICAL PURCHASING AND RECEIVING DATA ANALYSIS}


1997 EPCRA 313 Toxic Chemical Release Inventory Report 
Pure EPCRA 313 Chemicals from ACIS in Descending Order by Weight

\begin{tabular}{|c|c|c|}
\hline Total Weight (lb) & TRI Chemicals & CAS Numbers \\
\hline 11223.58 & CHLORINE & 7782505 \\
\hline 7066.84 & NITRIC ACID & 7697372 \\
\hline 5933.21 & HYDROCHLORIC ACID & 7647010 \\
\hline 3088.70 & METHYL ETHYL KETONE & 78933 \\
\hline 2450.70 & ETHYLENE GLYCOL & 107211 \\
\hline 2095.15 & METHANOL & 67561 \\
\hline 1942.95 & CHLORODIFLUOROMETHANE & 75456 \\
\hline 1690.83 & DICHLOROMETHANE & 75092 \\
\hline 1542.02 & BROMINE & 7726956 \\
\hline 1478.07 & $\begin{array}{ll}\text { 2-PROPANOL } & \text { (2-PROPANOL, } \\
\text { ANHYDROUS) } & \text { (ISOPROPANOL) }\end{array}$ & 67630 \\
\hline 1328.60 & ACETONITRILE & 75058 \\
\hline 1306.48 & 1,1,1-TRICHLORETHANE & 71556 \\
\hline 986.52 & PHOSPHORIC ACID $85 \%$ & 7664382 \\
\hline 678.51 & CHLOROFORM & 67663 \\
\hline 606.88 & HYDROGEN SULFIDE & 7783064 \\
\hline 599.48 & ALPHA ALUMINUM OXIDE & 1344281 \\
\hline 484.94 & SULFURIC ACID & 7664939 \\
\hline 425.35 & TOLUENE & 108883 \\
\hline 326.46 & AMMONIA, 7N IN METHANOL & 7664417 \\
\hline 255.07 & $\begin{array}{l}\text { 1,1,2-TRICHLORO-1,2,2- } \\
\text { TRIFLUOROETHANE }\end{array}$ & 76131 \\
\hline 236.09 & ALUMINUM & 7429905 \\
\hline 200.41 & HYDROFLUORIC ACID & 7664393 \\
\hline 170.64 & PHOSPHINE & 7803512 \\
\hline 143.97 & BENZENE & 71432 \\
\hline 120.77 & 1,1,2-TRICHLOROETHANE & 79005 \\
\hline 108.64 & PROPYLENE & 115071 \\
\hline 94.28 & ETHYLENE DICHLORIDE & 107062 \\
\hline 74.32 & N,N-DIMETHYLFORMAMIDE & 68122 \\
\hline 49.23 & MERCURY & 7439976 \\
\hline 46.11 & CYCLOHEXANE & 110827 \\
\hline 41.13 & DICHLORODIFLUOROMETHANE & 75718 \\
\hline 39.88 & 1,4-DIOXANE & 123911 \\
\hline 38.81 & XYLENE & 1330207 \\
\hline 30.16 & STYRENE MONOMER, INHIBITED & 100425 \\
\hline
\end{tabular}




\begin{tabular}{|c|c|c|}
\hline Total Weight (lb) & TRI Chemicals & CAS Numbers \\
\hline 28.83 & PYRIDINE & 110861 \\
\hline 28.68 & BROMOFORM & 75252 \\
\hline 28.66 & 1-METHYL-2-PYRROLIDINONE & 872504 \\
\hline 25.86 & CHLORSULFURON & 64902723 \\
\hline 25.84 & N-BUTYL ALCOHOL & 71363 \\
\hline 23.44 & COPPER & 7440508 \\
\hline 22.85 & CARBON TETRACHLORIDE & 56235 \\
\hline 20.44 & FORMIC ACID $88 \%$ & 64186 \\
\hline 20.12 & LEAD & 7439921 \\
\hline 19.38 & TRICHLOROETHYLENE & 79016 \\
\hline 18.42 & CARBON DISULFIDE & 75150 \\
\hline 18.11 & FORMALDEHYDE SOLUTION & 50000 \\
\hline 16.09 & 4-NITROPHENOL & 100027 \\
\hline 16.02 & ETHYLENE & 74851 \\
\hline 14.51 & DIETHANOLAMINE & 111422 \\
\hline 13.35 & MOLYBDENUM (VI)OXIDE & 1313275 \\
\hline 12.57 & COLLODIAL SILVER & 7440224 \\
\hline 11.88 & TITANIUM TETRACHLORIDE & 7550450 \\
\hline 11.78 & TRIETHYLAMINE & 121448 \\
\hline 9.23 & DIBUTYL PHTHALATE & 84742 \\
\hline 8.82 & HYDROQUINONE & 123319 \\
\hline 8.27 & 1,2,3-TRICHLOROPROPANE & 96184 \\
\hline 8.23 & ZINC & 7440666 \\
\hline 7.99 & COBALT & 7440484 \\
\hline 7.96 & PHENOL & 108952 \\
\hline 7.72 & NICKEL & 7440020 \\
\hline 7.50 & HEXANE & 110543 \\
\hline 6.80 & P-XYLENE & 106423 \\
\hline 5.64 & ANTIMONY & 7440360 \\
\hline 5.62 & O-DICHLOROBENZENE & 95501 \\
\hline 5.29 & METHYL ISOBUTYL KETONE & 108101 \\
\hline 5.28 & 1,1,2,2-TETRACHLOROETHANE & 79345 \\
\hline 5.06 & METHYL TERT-BUTYL ETHER & 1634044 \\
\hline 4.98 & ACRYLAMIDE & 79061 \\
\hline 4.98 & LITHIUM CARBONATE & 554132 \\
\hline 4.52 & BENZYL CHLORIDE & 100447 \\
\hline
\end{tabular}




\begin{tabular}{|c|c|c|}
\hline Total Weight (lb) & TRI Chemicals & CAS Numbers \\
\hline 4.42 & HEXAMETHYLPHOSPHORAMIDE & 680319 \\
\hline 3.97 & ETHYL ACRYLATE & 140885 \\
\hline 3.97 & METHYL IODIDE & 74884 \\
\hline 3.67 & CHLOROBENZENE & 108907 \\
\hline 3.65 & TERT-BUTYL ALCOHOL & 75650 \\
\hline 3.38 & THALLIUM 10MG/ML IN 10\% NITRIC ACID & 7440280 \\
\hline 3.31 & MANGANESE & 7439965 \\
\hline 3.19 & CHROMIUM & 7440473 \\
\hline 3.15 & SELENIUM & 7782492 \\
\hline 2.43 & NAPHTHALENE & 91203 \\
\hline 2.26 & SODIUM AZIDE & 26628228 \\
\hline 2.20 & MALEIC ANHYDRIDE & 108316 \\
\hline 2.20 & BORON TRIFLUORIDE & 7637072 \\
\hline 2.20 & O-XYLENE & 95476 \\
\hline 2.13 & 2-METHOXYETHANOL & 109864 \\
\hline 2.07 & VINYL ACETATE & 108054 \\
\hline 1.92 & M-XYLENE & 108383 \\
\hline 1.91 & ETHYLBENZENE & 100414 \\
\hline 1.91 & CADMIUM 10MG/ML IN 10\% NITRIC ACID & 7440439 \\
\hline 1.87 & CHLOROACETIC ACID & 79118 \\
\hline 1.87 & BENZOYL PEROXIDE & 94360 \\
\hline 1.85 & ACROLEIN, INHIBITED & 107028 \\
\hline 1.66 & 1,2,4-TRICHLOROBENZENE & 120821 \\
\hline 1.47 & DIMETHYL SULFATE & 77781 \\
\hline 1.37 & ANILINE & 62533 \\
\hline 1.30 & $\begin{array}{l}\text { ARSENIC STANDARD 10MG/ML } \\
\text { 15\%NITRIC ACID }\end{array}$ & 7440382 \\
\hline 1.10 & SODIUM NITRITE & 7632000 \\
\hline 1.10 & 2-NITROPROPANE & 79469 \\
\hline 1.10 & METHYL CHLOROFORMATE & 79221 \\
\hline 1.10 & METHYLENE BISPHENYL ISOCYANATE & 101688 \\
\hline 1.05 & BARIUM $99 \%$ & 7440393 \\
\hline 0.99 & PROPYLENE OXIDE & 75569 \\
\hline 0.82 & VANADIUM & 7440622 \\
\hline 0.78 & 2,4-DINITROTOLUENE & 121142 \\
\hline 0.77 & URETHANE & 51796 \\
\hline 0.75 & BROMOMETHANE $2.0 \mathrm{M}$ IN ETH & 74839 \\
\hline
\end{tabular}




\begin{tabular}{|c|c|c|}
\hline Total Weight (lb) & TRI Chemicals & CAS Numbers \\
\hline 0.56 & ETHYLENE DIBROMIDE & 106934 \\
\hline 0.55 & DINITRO-ORTHO-CRESOL & 534521 \\
\hline 0.55 & ACETONE CYANOHYDRIN, STABILIZED & 75865 \\
\hline 0.54 & GRAM SAFRANIN & 77736 \\
\hline 0.54 & PROPARGYL ALCOHOL & 107197 \\
\hline 0.53 & METHYL ACRYLATE, INHIBITED & 96333 \\
\hline 0.46 & O-ANISIDINE & 90040 \\
\hline 0.44 & HEXAMETHYLENE DIISOCYANATE & 822060 \\
\hline 0.44 & THIOUREA & 62566 \\
\hline 0.44 & 3-CHLORO-2-METHYLPROPENE & 563473 \\
\hline 0.43 & ACETALDEHYDE & 75070 \\
\hline 0.42 & N,N-DIMETHYLANILINE & 121697 \\
\hline 0.38 & 2-ETHOXYETHANOL & 110805 \\
\hline 0.35 & ISOBUTYLALDEHYDE & 78842 \\
\hline 0.28 & ACETAMIDE & 60355 \\
\hline 0.23 & O-CRESOL & 95487 \\
\hline 0.23 & ALLYL CHLORIDE & 107051 \\
\hline 0.22 & CHLOROMETHANE & 74873 \\
\hline 0.22 & ALLYLAMINE & 107119 \\
\hline 0.22 & $\begin{array}{l}\text { PHOSPHORUS LUMP RED ION } \\
\text { IMPLANTATION GR. }\end{array}$ & 7723140 \\
\hline 0.22 & CHLOROMETHYL METHYL ETHER & 107302 \\
\hline 0.22 & PICRIC ACID (2,4,6-TRINITROPHENOL) & 88891 \\
\hline 0.22 & QUINONE & 106514 \\
\hline 0.22 & CHLOROETHANE & 75003 \\
\hline 0.22 & RHODAMINE B & 81889 \\
\hline 0.22 & IRON PENTACARBONYL & 13463406 \\
\hline 0.22 & RHODAMIN 6G & 989388 \\
\hline 0.19 & ACRYLONITRILE & 107131 \\
\hline 0.19 & ALLYL ALCOHOL & 107186 \\
\hline 0.14 & FLUORINE $10 \%$ IN NITROGEN & 7782414 \\
\hline 0.13 & BERYLLIUM & 7440417 \\
\hline 0.12 & 2,4,6-TRICHLOROPHENOL & 88062 \\
\hline 0.11 & 1,4-PHENYLENEDIAMINE & 106503 \\
\hline 0.11 & 2,6-DINITROTOLUENE & 606202 \\
\hline 0.11 & BISPHENOL & 80057 \\
\hline 0.11 & THORIUM DIOXIDE & 1314201 \\
\hline
\end{tabular}




\begin{tabular}{|c|c|c|}
\hline Total Weight (lb) & TRI Chemicals & CAS Numbers \\
\hline 0.10 & CYCLOHEXANOL & 108930 \\
\hline 0.07 & 1,3-DICHLOROPROPENE & 542756 \\
\hline 0.07 & 2,3-DICHLORO-1-PROPENE & 78886 \\
\hline 0.06 & BETA-PROPIOLACTONE & 57578 \\
\hline 0.06 & BIPHENYL & 92524 \\
\hline 0.06 & 1,2-DIPHENYLHYDRAZINE & 122667 \\
\hline 0.06 & $\begin{array}{l}\text { P-PHENYLENEDIAMINE } \\
\text { DIHYDROCHLORIDE }\end{array}$ & 624180 \\
\hline 0.06 & 2,2-BIOXIRANE & 1464535 \\
\hline 0.06 & NITRAPYRIN & 1929824 \\
\hline 0.02 & BORON TRICHLORIDE $10 \%$ WT & 10294345 \\
\hline 0.02 & P-CRESOL & 106445 \\
\hline 0.02 & STYRENE OXIDE & 96093 \\
\hline 0.02 & 2,4-DIMETHYLPHENOL & 105679 \\
\hline 0.01 & PENTACHLCROPHENOL & 87865 \\
\hline 0.01 & 2-NITROPHENOL & 88755 \\
\hline 0.01 & $\begin{array}{l}\text { 2-METHYL-5-NITROANILINE [5-NITRO-O- } \\
\text { TOLUIDINE] }\end{array}$ & 99558 \\
\hline 0.01 & P-ANISIDINE & 104949 \\
\hline 0.01 & 1,1,1,2-TETRACHLOROETHANE & 630206 \\
\hline 0.01 & 2,4-DINITROPHENOL & 51285 \\
\hline 0.01 & M-DINITROBENZENE & 99650 \\
\hline 0.01 & 3,3'-DIMETHOXYBENZIDINE & 119904 \\
\hline 0.01 & 2,4-DICHLOROPHENOL & 120832 \\
\hline 0.01 & 2-AMINO-4,6-DINITROTOLUEN & 98953 \\
\hline 0.00 & BROMODICHLOROMETHANE & 75274 \\
\hline 0.00 & BIS(2-CHLOROETHOXY)METHANE & 111911 \\
\hline 0.00 & BIS(2-ETHYLHEXYL)PHTHALATE & 117817 \\
\hline 0.00 & OSMIUM (VIII) OXIDE & 20816120 \\
\hline 0.00 & 1,1-DICHLOROETHANE & 75343 \\
\hline 0.00 & BENZO(A)PYRENE & 50328 \\
\hline
\end{tabular}




\section{APPENDIX B}

\section{SUBCONTRACTOR CHEMICAL USAGE DATA}


1997 EPCRA 313 Toxic Chemical Release Inventory Report 
LANL SUBCONTRACTOR'S ON-SITE CHEMICAL USE FOR 1997

\begin{tabular}{|c|c|c|c|c|}
\hline Subcontractor & \multicolumn{2}{|c|}{ Chemical Type and Usage } & $\begin{array}{c}\text { Was } \\
\text { Chemical } \\
\text { Use } \\
\text { Included in } \\
\text { LANL's } \\
\text { Chemical } \\
\text { Inventory? }\end{array}$ & $\begin{array}{c}\text { Subcontractor } \\
\text { Contact/ Comments }\end{array}$ \\
\hline SAIC & \multicolumn{2}{|l|}{ None } & $N / A$ & Carmella Romero \\
\hline Weston & \multicolumn{2}{|l|}{ None } & $N / A$ & Pat Medina \\
\hline Radian & \multicolumn{2}{|l|}{ None } & $\mathrm{N} / \mathrm{A}$ & Cindy Backlund \\
\hline ICF Kaiser & \multicolumn{2}{|c|}{ Nitric Acid } & Yes & Loraine Rios \\
\hline ERM Golder & $\begin{array}{l}\text { Methanol } \\
\text { Sulfuric acid } \\
\text { Hydrochloric acid } \\
\text { Nitric acid } \\
\text { Hydrogen cyanide } \\
\text { Isopropyl alcohol }\end{array}$ & $\begin{array}{l}1 \mathrm{gal} \\
1 \mathrm{gal} \\
1 \mathrm{gal} \\
1 \mathrm{gal} \\
2 \mathrm{ml} \\
1 \mathrm{gal}\end{array}$ & Yes & $\begin{array}{l}\text { Jim Santo } \\
\text { Mary Frank }\end{array}$ \\
\hline JCNNM & $\begin{array}{l}\text { Sulfuric acid } \\
\text { Chlorine }\end{array}$ & $\begin{array}{l}7,724 \mathrm{gal} \\
11,500 \mathrm{lb}\end{array}$ & Yes & Suzanne Moore \\
\hline LATA & None & & $N / A$ & Bob Hull \\
\hline Butler & - None & & $N / A$ & Steve Garcia \\
\hline IT & None & & $\mathrm{N} / \mathrm{A}$ & Glenn VanDerpoel \\
\hline Merrick & None & & N/A & Kirk Ellard \\
\hline Weirich & None & & N/A & Joanne Volak \\
\hline The Plus Group & None & & $\mathrm{N} / \mathrm{A}$ & Ken Kollecker \\
\hline Benchmark & None & & N/A & Ed Horst \\
\hline $\begin{array}{l}\text { Com Force } \\
\text { (Ray Rashkin) }\end{array}$ & None & & N/A & Karen Neeley \\
\hline Techlaw Inc. & None & & N/A & Pat Shanley \\
\hline Fire Department & Fire Suppressant Foar & n $25 \mathrm{gal}$ & $\mathrm{N} / \mathrm{A}$ & Juan Pacheco \\
\hline Bectel & None & & N/A & $\begin{array}{l}\text { Bob Parks or } \\
\text { John Sutton }\end{array}$ \\
\hline
\end{tabular}




\section{APPENDIX C}

\section{FORM R REPORTS FOR NITRIC ACID}


1997EPCRA 3133 Toxic Chemical Release Inventory Report 


\section{EPA}

United States

Environmental Protection

Agency
FORM R
TOXIC CHEMICAL RELEASE INVENTORY REPORTING FORM

Section 313 of the Emergency Planning and Community Right-to-Know Act of 1986, also known as Title III of the Superfund Amendments and Reauthorization Act

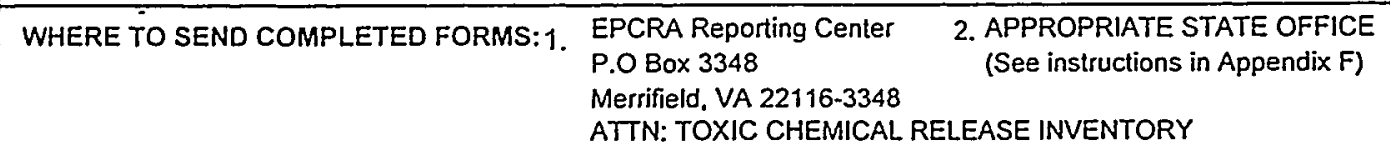

Important: See instructions to determine when "Not Applicable (NA)" boxes should be checked.

\section{PART I. FACILITY IDENTIFICATION INFORMATION \\ SECTION 1.REPORTING YEAR 1997 \\ SECTION 2. TRADE SECRET INFORMATION}

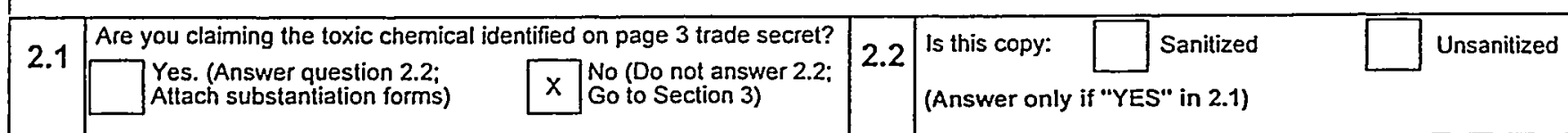

\section{SECTION 3. CERTIFICATION (Important: Read and sign after completing all form sections.)}

I hereby certify that I have reviewed the attached documents and that, to the best of my knowledge and belief, the submitted.

information is true and complete and that the amounts and values in this report are accurate based on reasonable estimates

using data available to the preparers of this report.

Name and official title of owner/operator or senior management official:

DOUGLAS STAVERT
ACTING AIR OUALTTY GROUP LEADER
$=$

\section{SECTION 4. FACILITY IDENTIFICATION}

\begin{tabular}{l|l}
4.1 & $\begin{array}{l}\text { Facility or Establishment Name } \\
\text { LOS ALAMOS NATIONAL LABORATORY }\end{array}$
\end{tabular}

\section{Street}

P.O. BOX 1663

City/County/State/Zip Code

LOS ALAMOS LOS ALAMOS

\begin{tabular}{l|l} 
Lail & \\
LOS
\end{tabular}

Signature:

$06 / 26 / 98$

Date Signed:

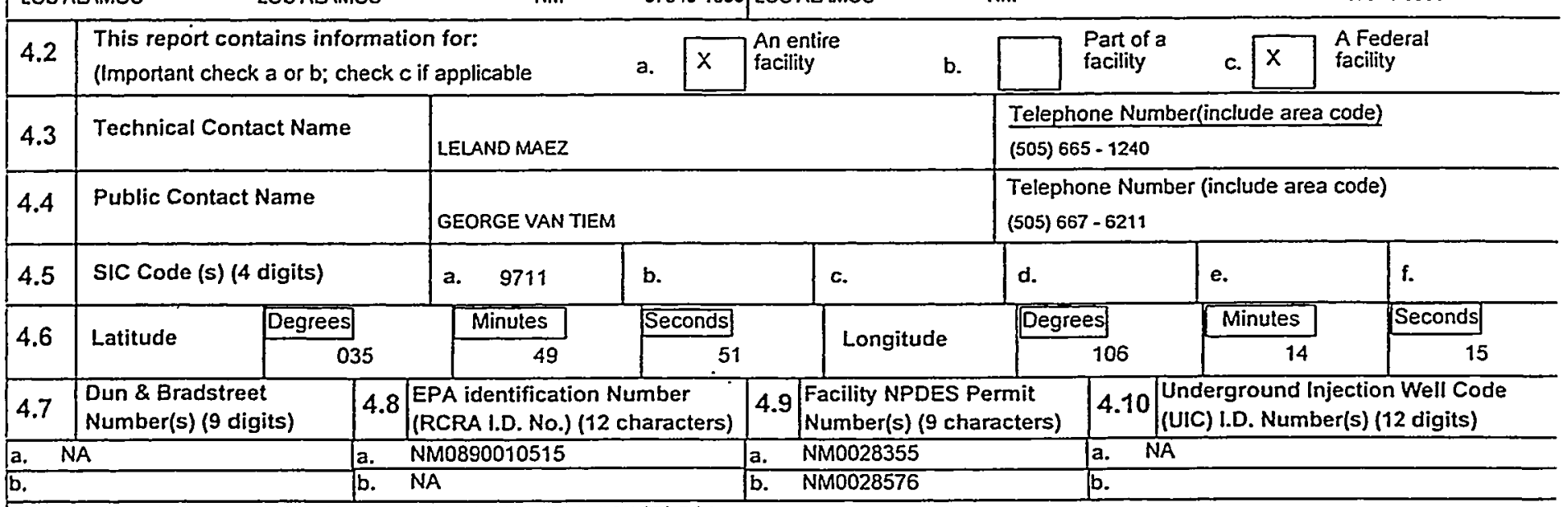

\section{SECTION 5. PARENT COMPANY INFORMATION}

\begin{tabular}{|l|l|l|l|l|}
\hline 5.1 & Name of Parent Company & & \multicolumn{2}{|l|}{ U.S. DEPARTMENT OF ENERGY } \\
\hline 5.2 & Parent Company's Dun \& Bradstreet Number & $\mathrm{x}$ & NA & \\
\hline
\end{tabular}




\section{EPA FORM R \\ PART II. CHEMICAL-SPECIFIC INFORMATION}

TRI FACILITY ID NUMBER

87545LSLMSLOSAL

Toxic Chemical, Category or Generic Name NITRIC ACID

\section{SECTION 1. TOXIC CHEMICAL IDENTITY (Important: DO NOT complete this section if you complete Section 2 below.)}

1.1 CAS Number (Important: Enter only one number exactly as it appears on the Section 313 list. Enter category code if reporting a chemical category.) 007697372

1.2 Toxic Chemical or Chemical Category Name (Important: Enter only one name exactly as it appears on the Section 313 list.) NITRIC ACID

1.3 Generic Chemical Name (lmportant: Completronly if Part 1, Section 2.1 is checked "yes". Generic Name must be structurally descriptive) NA

\section{SECTION 2. MIXTURE COMPONENT IDENTITY (Important: DO NOT complete this section if you}

2.1 Generic Chemital Name Provided by Supplier (Important: Maximum of 70 characters, including numbers, letters, spaces, and punctuation.) NA

\section{SECTION 3. ACTIVITIES AND USES OF THE TOXIC CHEMICAL AT THE FACILITY}

(Important: Check all that apply.)

\begin{tabular}{l|l|l|l|l|l|l}
\hline 3.1 & Manufacture the toxic chemical: & 3.2 & Process the toxic chemical: & 3.3 & Otherwise use the toxic chemical:
\end{tabular}

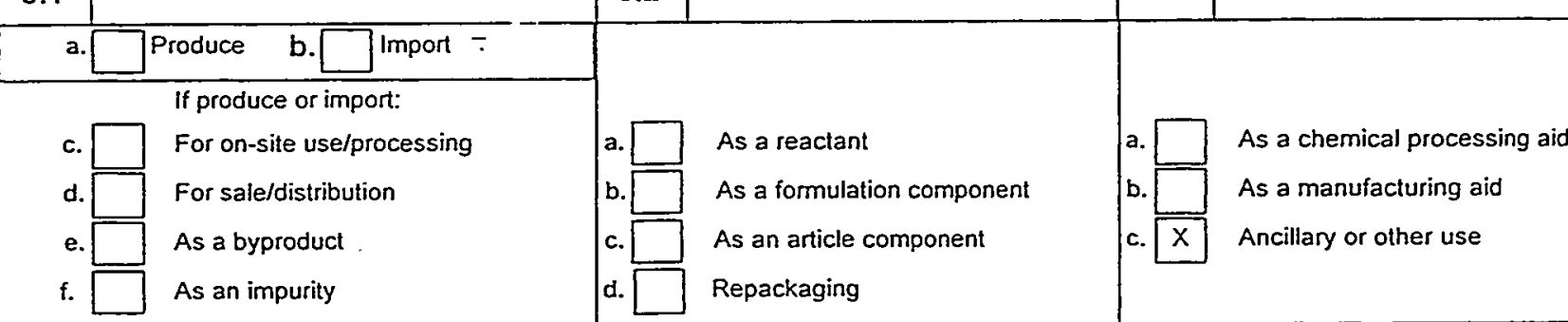

SECTION 4. MAXIMUM AMOUNT OF THE TOXIC CHEMICAL ON-SITE AT ANY TIME DURING THE CALENDAR YEAR

\begin{tabular}{l|l|l}
\hline 4.1 & 04 & (Enter two-digit code from instruction package.) \\
\hline
\end{tabular}

SECTION 5. QUANTITY OF THE TOXIC CHEMICAL ENTERING EACH ENVIRONMENTAL MEDIUM

\begin{tabular}{|c|c|c|c|c|c|c|}
\hline & & & & $\begin{array}{l}\text { A.Total Release (pounds/year)(enter } \\
\text { range from instructions or estimate. }\end{array}$ & $\begin{array}{l}\text { B. Basis of estimate } \\
\text { (enter code) }\end{array}$ & C. \% From Stormwater \\
\hline 5.1 & $\begin{array}{l}\text { Fugitive or non-point } \\
\text { air emissions }\end{array}$ & NA & $x$ & NA & & \multirow{3}{*}{ 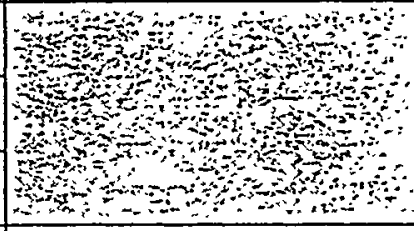 } \\
\hline 5.2 & $\begin{array}{l}\text { Stack or point } \\
\text { air emissions }\end{array}$ & NA & & 720 & 0 & \\
\hline 5.3 & \multicolumn{3}{|c|}{$\begin{array}{l}\text { Discharges to receiving streams or } \\
\text { water bodies (enter one name per box) }\end{array}$} & \multicolumn{2}{|c|}{$\therefore \quad \because 40$} & \\
\hline & \multicolumn{3}{|c|}{ Stream or Water Body Name } & & & \\
\hline 5.3 .1 & \multicolumn{3}{|l|}{ NA } & & & . \\
\hline \multicolumn{7}{|l|}{5.3 .2} \\
\hline \multicolumn{7}{|l|}{ 5.3.3 } \\
\hline 5.4 .1 & $\begin{array}{l}\text { Underground Injection on-site } \\
\text { to Class I Wells }\end{array}$ & NA & $\bar{x}$ & NA & & \\
\hline 5.4 .2 & $\begin{array}{l}\text { Underground injection on-site } \\
\text { to Class II-V Wells }\end{array}$ & NA & $x$ & NA & & \\
\hline
\end{tabular}




\section{EPA FORM R \\ PART II. CHEMICAL - SPECIFIC INFORMATION (CONTINUED)}

TRI FACILITY ID NUMBER

87545LSLMSLOSAL

Toxic Chemical, Category, or Generic Name

NITRIC ACID

SECTION 5. QUANTITY OF THE TOXIC CHEMICAL ENTERING EACH ENVIRONMENTAL MEDIUM

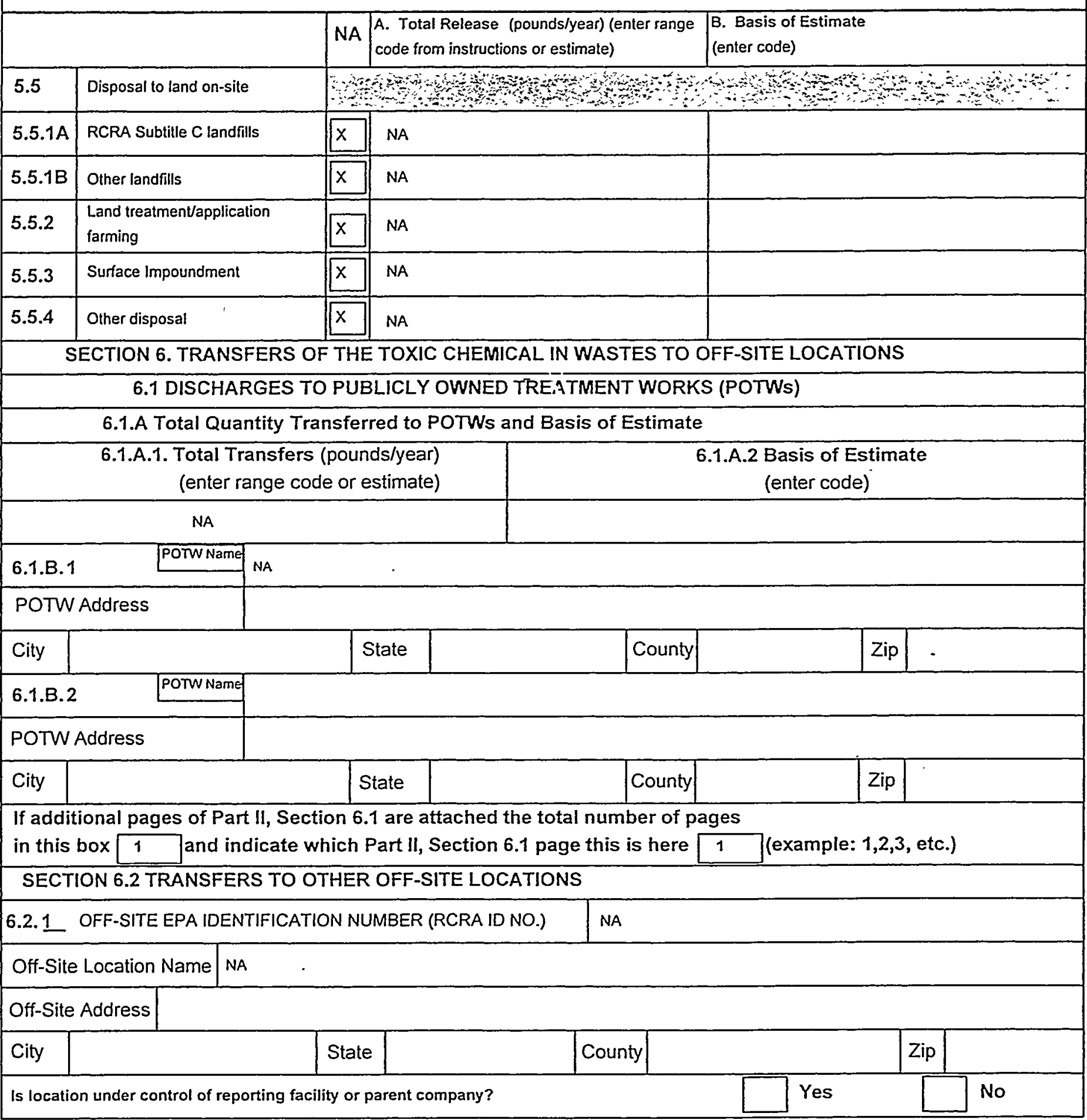




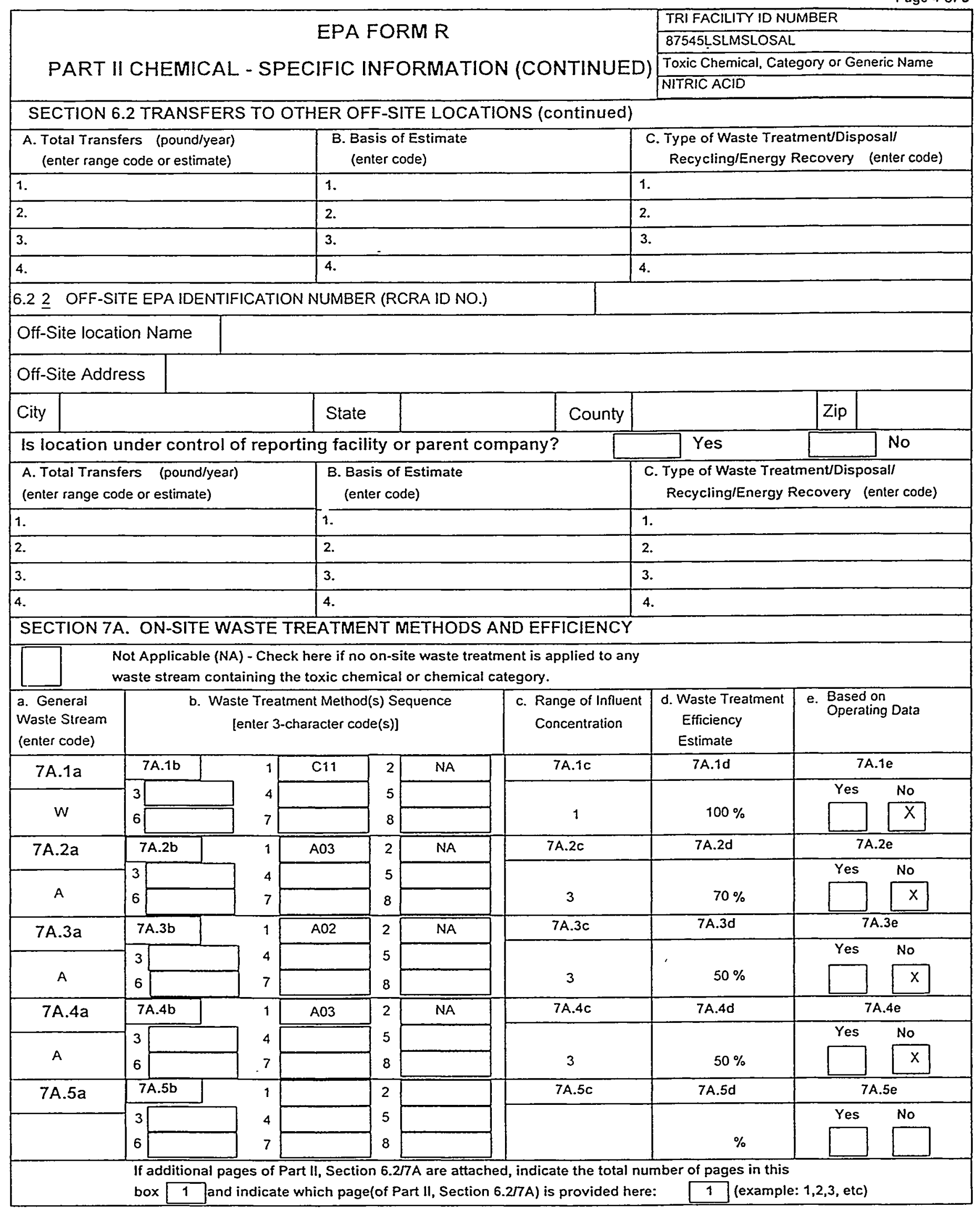




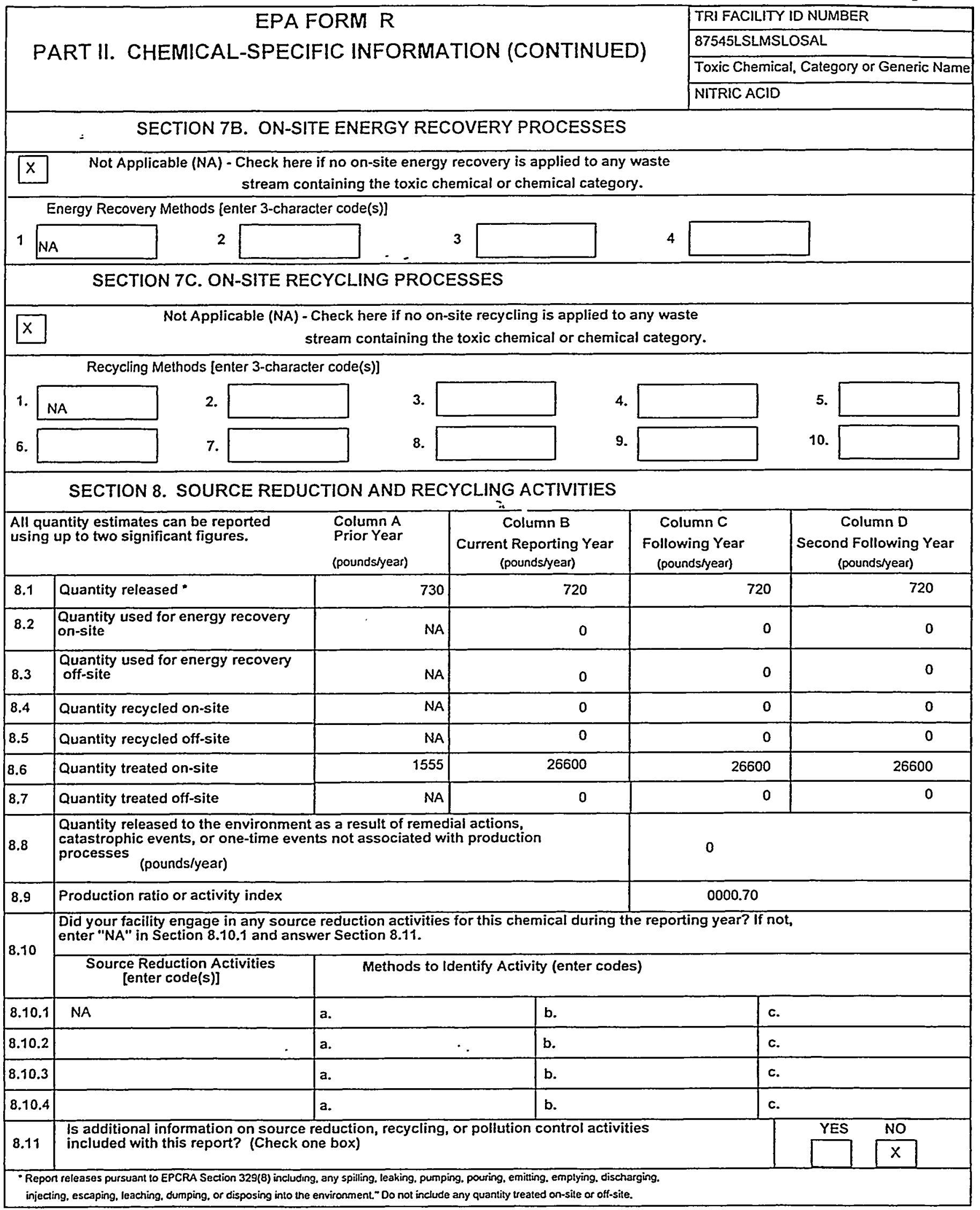




\section{EPA}

United States

Environmental Protection

Agency

\section{FORM R}

Section 313 of the Emergency Planning and Community Right-to-Know Act of 1986 , also known as Title III of the Superfund Amendments and Reauthorization Act
WHERE TO SEND COMPLETED FORMS:1. EPCRA Reporting Cente

P.O Box 3348

Merrifield, VA 22116-3348

ATTN: TOXIC CHEMICAL RELEASE INVENTORY
Form Approved OMB Number: 2070-0093

Approval Expires: 04/2000

TOXIC CHEMICAL RELEASE

INVENTORY REPORTING FORM

Page 1 of $?$

\section{Important: See instructions to determine when "Not Applicable (NA)" boxes should be checked.}

\section{PART I. FACILITY IDENTIFICATION INFORMATION \\ SECTION 1.REPORTING YEAR 1997 \\ SECTION 2. TRADE SECRET INFORMATION}

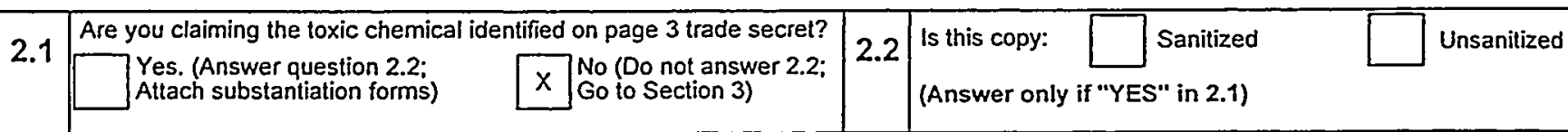

\section{SECTION 3. CERTIFICATION (Important: Read and sign after completing all form sections.)}

I hereby certify that I have reviewed the attached documents and that, to the best of my knowledge and belief, the submitted .

information is true and complete and that the amounts and values in this report are accurate based on reasonable estimates

using data available to the preparers of this report.

Name and official title of owner/operator or senior management official:

JOSEPH C. VOZELLA

ASSISTANT AREA MANAGER FOR E\&P

$-$

\begin{tabular}{|l|l|}
\hline Signature: & Date Signed: \\
\hline $06 / 26 / 98$
\end{tabular}

SECTION 4. FACILITY IDENTIFICATION

4.1 1 Facility or Establishment Name

U.S. DEPARTMENT OF ENERGY LOS ALAMOS NATIONAL LABORATORY

Street

528 EAST 35TH STREET

TRI Facility ID Number

87544SDLSL52835

Facility or Establishment Name or Mailing Address(if different from street address)

City/County/State/Zip Code

LOS ALAMOS

LOS ALAMOS

NM

87544-

Mailing Address

LOS ALAMOS AREA OFFICE

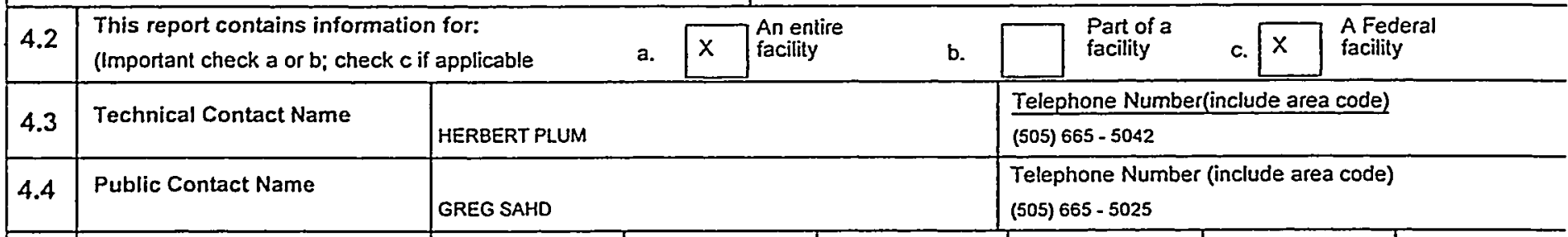

\begin{tabular}{|l|l|l|l|l|}
\hline 4.5 & SIC Code (s) (4 digits) & a. 9711 & b. NA & c. \\
\hline
\end{tabular}

\begin{tabular}{|l|l|l|l|l|l|}
\hline 4.6 & \multirow{2}{*}{ Latitude } & Degrees & Minutes & Seconds & Longitude \\
\cline { 3 - 6 } & 035 & 49 & 51 & \\
\hline
\end{tabular}

\begin{tabular}{|c|c|c|}
\hline d. & e. & f. \\
\hline Degrees & Minutes & Seconds \\
\hline 106 & 14 & 15 \\
\hline
\end{tabular}

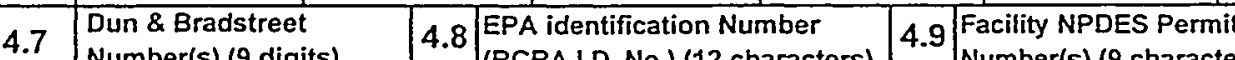

\begin{tabular}{|l|l|l|l|}
\hline \multicolumn{1}{|l|}{ Number(s) (9 digits) } & 4.8 & (RCRA 1.D. No.) (12 characters) \\
\hline a. NA & a. NM0890010515 \\
\hline b. NA & b. NA
\end{tabular}

a. NM0028355

4.10 Underground Injection Well Code

b. NM0028576

(UIC) I.D. Number(s) (12 digits)

SECTION 5. PARENT COMPANY INFORMATION

\begin{tabular}{|l|l|l|l|l|}
\hline 5.1 & Name of Parent Company & $\square$ NA & \multicolumn{2}{|l|}{ U.S. DEPARTMENT OF ENERGY } \\
\hline 5.2 & Parent Company's Dun \& Bradstreet Number & $x$ & NA & \\
\hline
\end{tabular}


EPA FORM $R$

PART II. CHEMICAL-SPECIFIC INFORMATION
TRI FACILITY ID NUMBER

87544 SDLSL52835

Toxic Chemical, Category or Generic Name

NITRIC ACID

\section{SECTION 1. TOXIC CHEMICAL IDENTITY $\quad \begin{aligned} & \text { (Important: DO NOT complete this section if you } \\ & \text { complete Section } 2 \text { below.) }\end{aligned}$}

1.1 CAS Number (lmportant: Enter only one number exactly as it appears on the Section 313 list. Enter category code if reporting a chernical category.) 007697372

1.2 Toxic Chemical or Chemical Category Name (Important: Enter only one name exactly as it appears on the Section 313 list.) NITRIC ACID

1.3 Generic Chemical Name (lmportant: Completeonly if Part 1, Section 2.1 is checked "yes". Generic Name must be structurally descriptive) NA

\section{SECTION 2. MIXTURE COMPONENT IDENTITY (Important: DO NOT complete this section if you}

\begin{tabular}{l|l}
2.1 & Generic Chemical Name Provided by Supplier (Important: Maximum of 70 characters, including numbers, letters, spaces, and pynctuation.) \\
\cline { 2 - 3 } & NA
\end{tabular}

SECTION 3. ACTIVITIES AND USES OF THE TOXIC CHEMICAL AT THE FACILITY (Important: Check all that apply.)

\begin{tabular}{l|l|l|l|l|l|l}
3.1 & Manufacture the toxic chemical: & 3.2 & Process the toxic chemical: & 3.3 & Otherwise use the toxic chemical:
\end{tabular}

a. $\square$ Produce b. $\square$ Import
c. $\square$ For on-site use/processing
d. $\square$ For sale/distribution
e. $\square$ As a byproduct
f. $\square$ As an impurity

\section{SECTION 4. MAXIMUM AMOUNT OF THE TOXIC CHEMICAL ON-SITE AT ANY TIME DURING THE CALENDAR YEAR}
4.1
04
(Enter two-digit code from instruction package.)

\section{SECTION 5. QUANTITY OF THE TOXIC CHEMICAL ENTERING EACH ENVIRONMENTAL MEDIUM}

\begin{tabular}{|c|c|c|c|c|c|c|}
\hline & & & & $\begin{array}{l}\text { A.Total Release (pounds/year)(enter } \\
\text { range from instructions or estimate. }\end{array}$ & $\begin{array}{l}\text { B. Basis of estimate } \\
\text { (enter code) }\end{array}$ & C. \% From Stormwater \\
\hline 5.1 & $\begin{array}{l}\text { Fugitive or non-point } \\
\text { air emissions }\end{array}$ & NA & $x$ & NA & & ond \\
\hline 5.2 & $\begin{array}{l}\text { Stack or point } \\
\text { air emissions }\end{array}$ & NA & & 720 & o & and \\
\hline 5.3 & $\begin{array}{l}\text { Discharges to receiving strear } \\
\text { water bodies (enter one name }\end{array}$ & $\begin{array}{l}\text { ams or } \\
\text { e per bc }\end{array}$ & & $h_{0}$ & 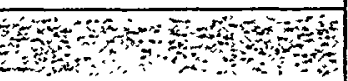 & ond \\
\hline & Stream or Water Body N & Name & & & & \\
\hline 5.3 .1 & NA & & & & & . \\
\hline 5.3.2 & & & & & & \\
\hline 5.3.3 & & & & & & \\
\hline 5.4 .1 & $\begin{array}{l}\text { Underground Injection on-site } \\
\text { to Class I Wells }\end{array}$ & NA & $x$ & NA & & \\
\hline 5.4 .2 & $\begin{array}{l}\text { Underground injection on-site } \\
\text { to Class II- } \vee \text { Wells }\end{array}$ & NA & $x$ & $\mathrm{NA}$ & & \\
\hline
\end{tabular}




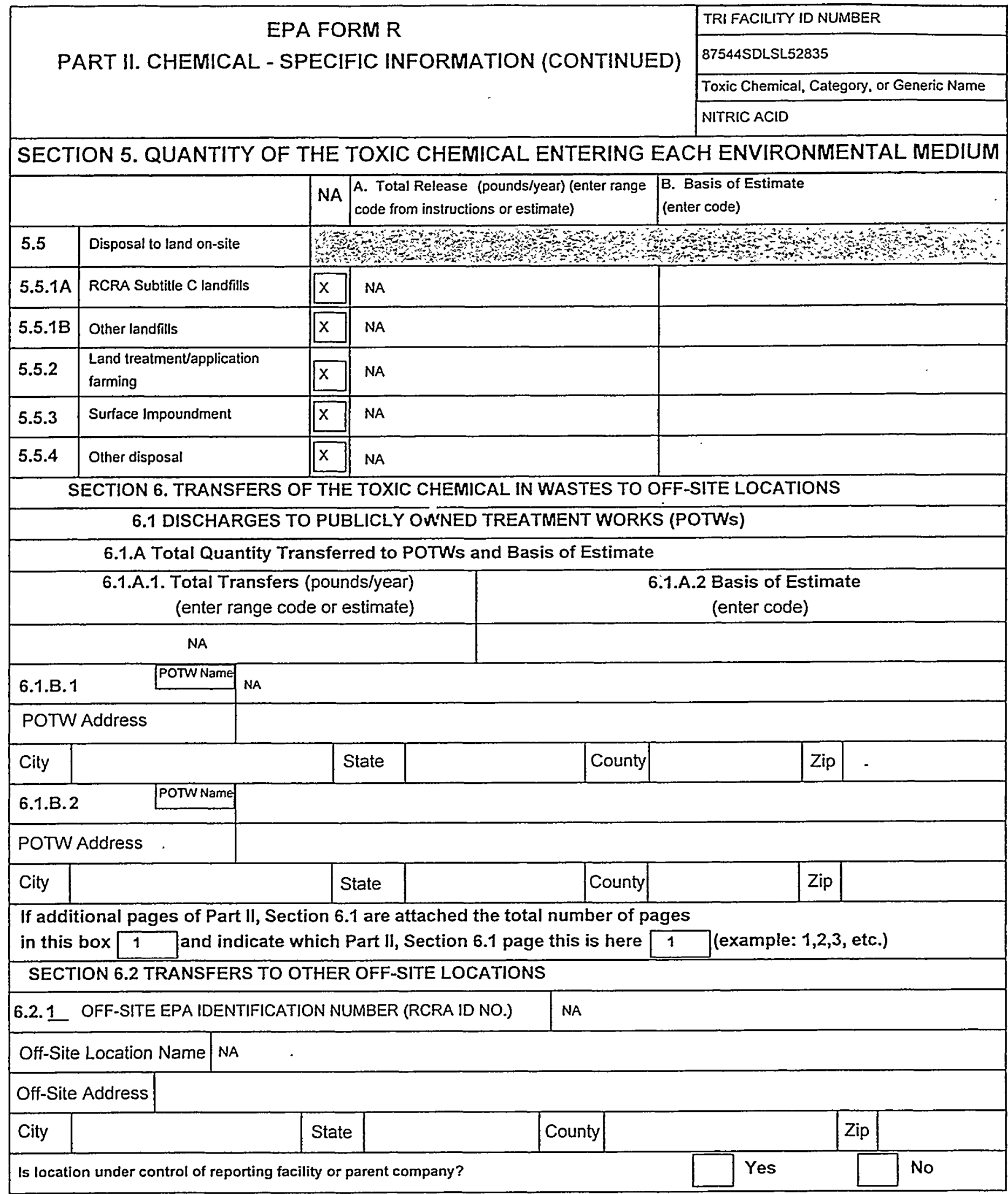




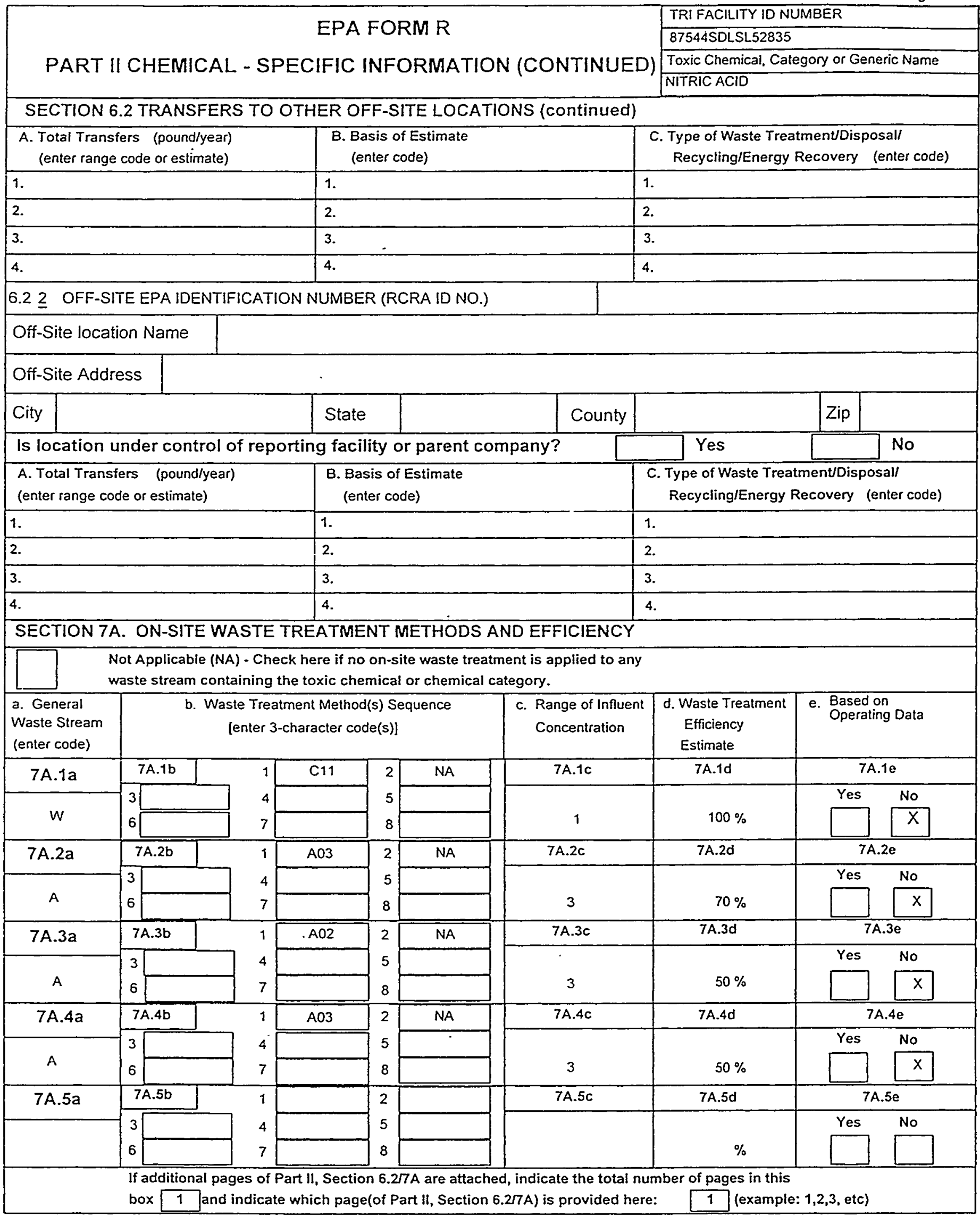




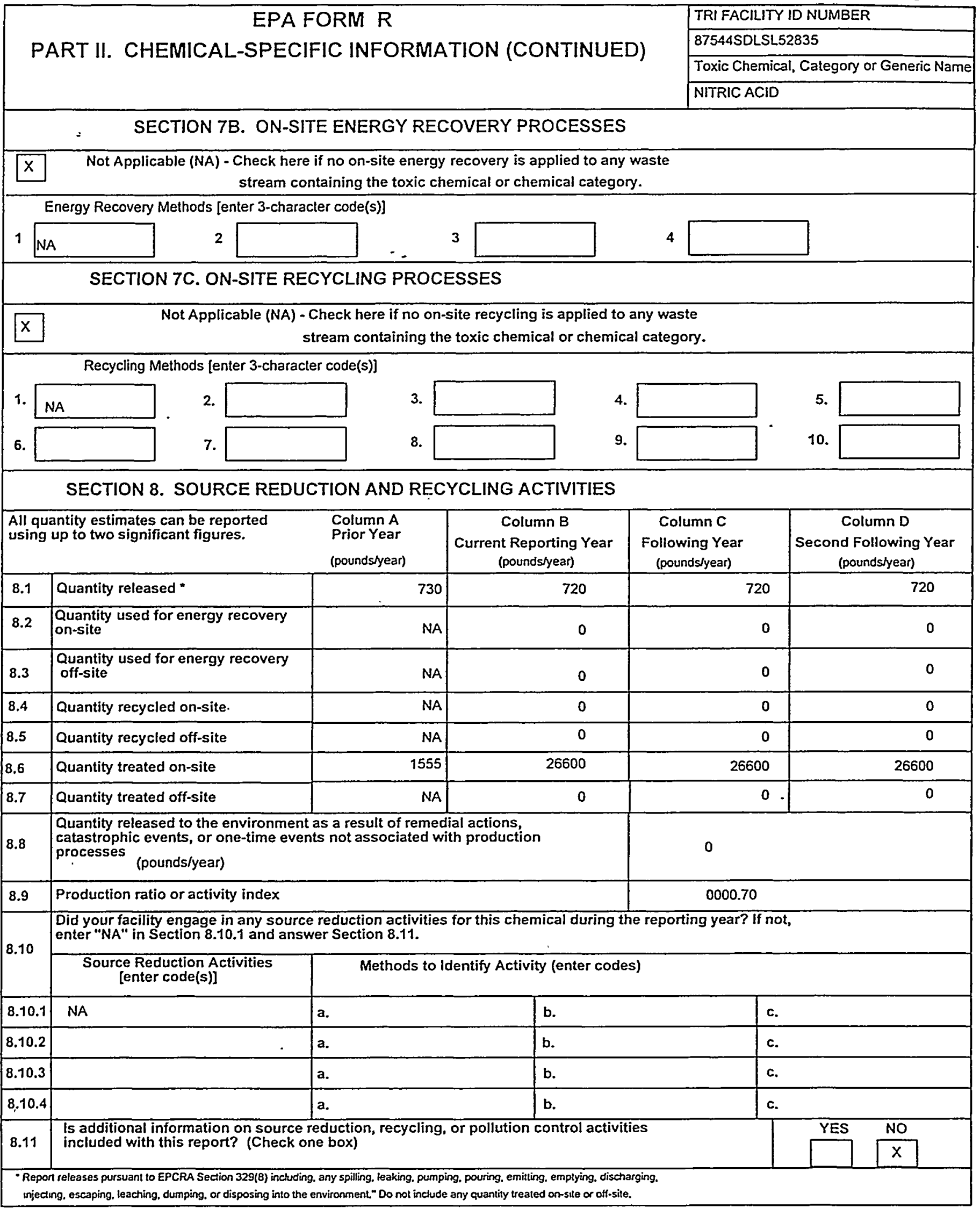




\section{APPENDIX D}

\section{TANKS 3.1 EIMISSION REPORTS FOR NITRIC ACID}




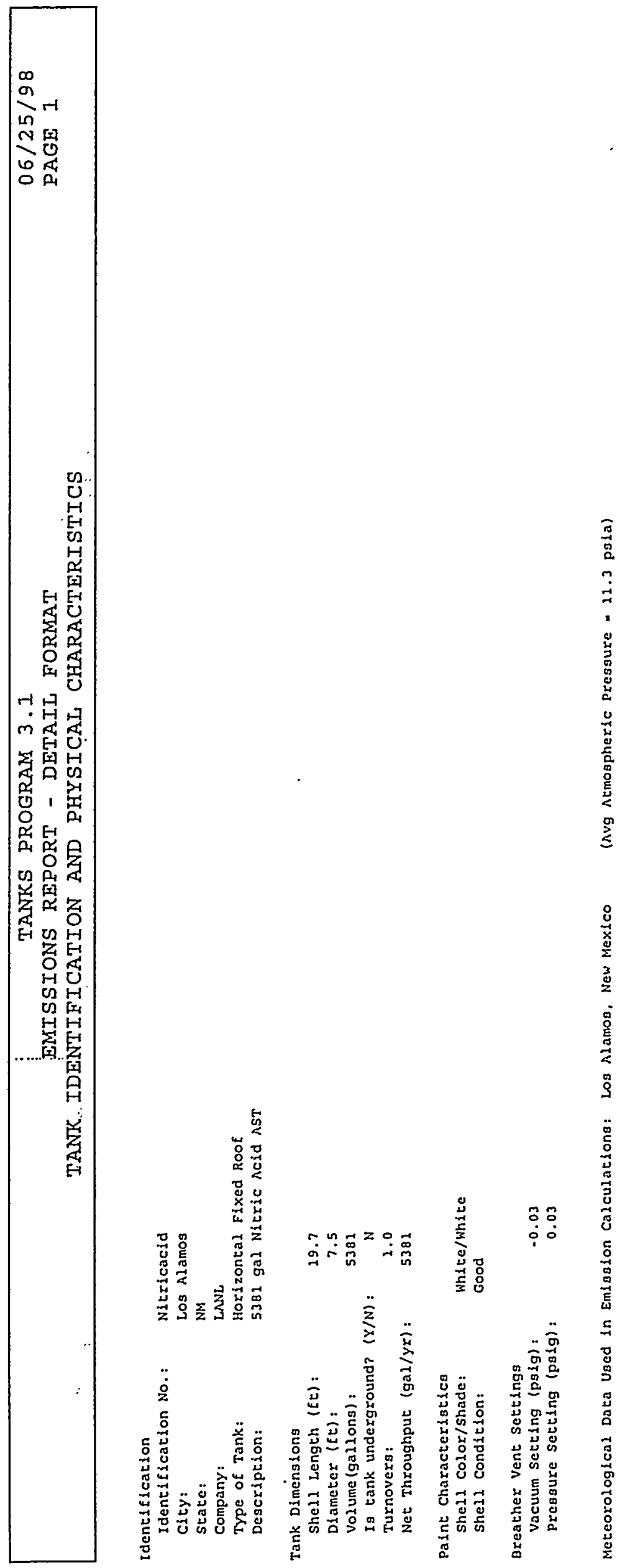


TANKS PROGRAM 3.1

\begin{tabular}{|c|c|c|c|c|c|c|c|c|c|c|c|c|}
\hline $11 \times$ ture/Component & Month & $\begin{array}{l}\text { Daily Liquid } \\
\text { Temperatures } \\
\text { Avg. Min. }\end{array}$ & $\begin{array}{l}\text { Surf. } \\
\text { (deg } F) \\
\operatorname{Max.}\end{array}$ & $\begin{array}{l}\text { Liquid } \\
\text { Bulk } \\
\text { Temp. } \\
\text { (deg F) }\end{array}$ & $\begin{array}{l}\text { Vapor } \\
\text { Avg. }\end{array}$ & $\begin{array}{l}\text { Pressures } \\
\text { Min. }\end{array}$ & $\begin{array}{l}\text { (pgia) } \\
\operatorname{Max}\end{array}$ & $\begin{array}{l}\text { Vapor } r \\
\text { Mol. } \\
\text { Helght }\end{array}$ & $\begin{array}{l}\text { Mass } \\
\text { Eract. }\end{array}$ & $\begin{array}{l}\text { Mass } \\
\text { Fract. }\end{array}$ & $\begin{array}{l}\text { Mol. } \\
\text { Welght }\end{array}$ & $\begin{array}{l}\text { Basis for vapor pressure } \\
\text { Calcularions }\end{array}$ \\
\hline Jieric Acid (70wer) & A11 & $50.56 \quad 44.12$ & $57.00^{\circ}$ & 48.12 & 0.0746 & 60.0610 & 0.0920 & 63.020 & & & 63.02 & Option 1 \\
\hline
\end{tabular}


Vapor Space volume (cu $\mathrm{ft}$ )

Vapor Density ( $1 \mathrm{~b} / \mathrm{cu} f \mathrm{f})$ :

vapor Space Expansion Factor:

vented Vapor Saturation factor;

0.0009

0.0009

0.047892

0.985394

rank vapor space volume

Vapor Space volume (cu $f(t)$ :

Tank Diameter $(\mathrm{Et})$ :

Effective Diameter ( $f t)$

552.93

vapor space Outage (ft):

Tank Shell keighe

Vapor Density

Vapor Density ( $\mathrm{lb} / \mathrm{cu} \mathrm{ft}$ ):

Vapor Molecular Weight (2b/1b-mole).

vapor Pressure at Dally Average Liquid

Surface Temperature (psia):

Dally Avg. Liquid Surface Temp. (deg R):

Dally Average Amblent Temp. (deg. R):

Ideal Gas Congtant $R$

(psia cuft /(lb-mole-deg $R)$ ):

Liquid Bulk Temperature (deg R)

Tank Paint Solar Absorptance:

Dally Total Solar Insolation

Factor (Btu/sqftday):

0.0009

63.020000

0.071578

510.23

507.77

10.731

507.79

0.27

1827.00

Vapor Space Expansion Factor

Vapor Space Expansion Factor:

Dally Vapor Temperature Range (deg R)

Dally Vapor Pressure Range (psía).

Breacher vent Press. Setting Range (psial.

Vertia)

Surface Temperature (psia).

vapor Pressuro at Dally Minimum Liquid Surface Temperature (pgia),

vapor Pressure at Dally Maximum Llquid

Surface Temperature (pia).

0.047891

25.76

0.030990

0.06

0.074578

0.061016

0.092006

510.23

Daily Min. Liquid Surface Temp. (deg R): $\quad 503.79$

Dally Max. Liquid Surface Temp. (deg R): $\quad 516.67$
23.70 
TANKS PROGRAM 3.1

EMISSIONS REPORT

DETAIL CALCULATIONS (AP-42), CONT,

Innual Emisgion calculations

vented vapor saturation Factor

Vented Vapor Saturation Factor:

vapor Pressure at Dally Average Liquíd

Surface Temperature (psia):

vapor Space Outage ( $t$ )

0.985394

0.074578

3.75

Working Losses (1b):

Vapor Molecular Weight (1b/1b-mole):

vapor Pressure at Dally Average Liquid

surface Temperature (psia):

Annual Net Throughput (gal/yr):

Turnover Factor:

Tank Diameter ( $f(t)$

Working Loss Product Factor,

0.6022
63.020000

0.074578

5381

2.0000

7.5

8.78

Total Losges (1b): 
TANKS PROGRAM 3.1

EMISSIONS REPORT - DETAIL FORMAT

$06 / 25 / 98$

INDIVIDUAL TANK EMISSION TOTALS

1 Emissions Report

1 Contents

standing

Horking Total

acid (7ower)

$0.60 \quad 8.78$

8.18

$\begin{array}{lll}8.28 & 0.60^{\circ} & 8.78\end{array}$ 


\section{APPENDIX E}

\section{TOXIC CHEMICAL USE THRESHOLD DATA SUMMMARY}




\section{Toxic Chemical-Use-Threshold Data Summary}

A variety of Laboratory resources were used in order to make the appropriate threshold determinations for toxic chemical use and subsequent Form $\mathrm{R}$ reporting under EPCRA 313. Below is an analysis of the data and an accuracy determination of that data.

\section{Pure Chemicals}

\begin{tabular}{|c|c|c|c|c|}
\hline Data Source & $\begin{array}{c}\text { Chemical Source or } \\
\text { Type }\end{array}$ & $\begin{array}{l}\text { Weight of EPCRA } \\
\text { Chemicals Captured for } \\
\text { Threshold Determination } \\
\text { (lb) }\end{array}$ & $\begin{array}{l}\text { \% Capture of EPCRA } \\
\text { Chemicals }\end{array}$ & $\overline{\text { Data Quality }}$ \\
\hline ACIS & $\begin{array}{l}\text { Fisher-supplied chemicals, } \\
\text { maintenance chemicals }\end{array}$ & 47,482 & 19 & $89^{a}$ \\
\hline Large Purchases & Nitric and sulfuric acids & 145,400 & 58 & $99^{b}$ \\
\hline $\begin{array}{l}\text { User-Supplied Process } \\
\text { Records }\end{array}$ & Beryllium and lead metals & 56,100 & 23 & $95^{\mathrm{c}}$ \\
\hline TOTAL & & 248,982 & 100 & $96^{\mathrm{d}}$ \\
\hline
\end{tabular}

"Analysis of 1996 procurement records evaluated against wall-to-wall inventory records indicated that ACIS is approximately $89 \%$ accurate at capturing the Laboratory's chemical inventory. This evaluation was submitted to the State of New Mexico in the Laboratory's 1997 emissions inventory report.

${ }^{b}$ Identifiable purchase records are estimated to be $99 \%$ to $100 \%$ accurate.

' Operation logbooks and records are estimated to be $95 \%$ accurate.

"Overall data quality is determined by multiplying the "\% Capture" and "Data Quality" columns and summing the products. 
Mixtures

\begin{tabular}{|l|l|c|c|c||}
\hline \hline Data Source & Chemical Source or Type & $\begin{array}{c}\text { Constituent Weight of } \\
\text { EPCRA Chemicals } \\
\text { Captured for Threshold } \\
\text { Determination (lb) }\end{array}$ & $\begin{array}{c}\% \text { Capture of EPCRA } \\
\text { Chemicals }\end{array}$ & Data Quality \\
\hline ACIS & $\begin{array}{l}\text { Fisher-supplied chemicals, } \\
\text { maintenance chemicals }\end{array}$ & 664 & 100 & $89^{\mathrm{a}}$ \\
\hline TOTAL & & $\mathbf{6 6 4}$ & $\mathbf{1 0 0}$ & $\mathbf{8 9 ^ { \mathrm { b } }}$ \\
\hline
\end{tabular}

${ }^{a}$ Analysis of 1996 procurement records evaluated against wall-to-wall inventory records indicated that ACIS is approximately $89 \%$ accurate at capturing the Laboratory's chemical inventory. This evaluation was submitted to the State of New Mexico in the Laboratory's 1997 emissions inventory report. ${ }^{1}$

'Overall data quality is determined by multiplying the "\% Capture" and "Data Quality" columns snd summing the products.

\section{Compounds}

\begin{tabular}{|c|c|c|c|c|}
\hline Data Source & Chemical Source or Type & $\begin{array}{l}\text { Weight of Compounds } \\
\text { Evaluated for the Presence of } \\
\text { EPCRA Chemicals for } \\
\text { Threshold Determination (lb.) }\end{array}$ & $\begin{array}{c}\% \text { Capture of } \\
\text { EPCRA Chemicals }\end{array}$ & Data Quality \\
\hline ACIS & $\begin{array}{l}\text { Fisher-supplied chemicals, } \\
\text { maintenance chemicals }\end{array}$ & 1,174 & 100 & $89^{a}$ \\
\hline $\begin{array}{l}\text { User-Supplied Process } \\
\text { Records }\end{array}$ & Nitrates and cyanides from $\mathrm{HE}$ & 15,070 & $0^{\mathrm{b}}$ & $0^{\mathrm{c}}$ \\
\hline TOTAL & & 16,244 & 100 & $89^{d}$ \\
\hline
\end{tabular}

${ }^{a}$ Analysis of 1996 procurement records evaluated against wall-to-wall inventory records indicated that ACIS is approximately $89 \%$ accurate at capturing the Laboratory's chemical inventory. This evaluation was submitted to the State of New Mexico in the Laboratory's 1997 emissions inventory report.

${ }^{b}$ No reportable EPCRA 313 chemicals were used or produced in explosive activities.

'Operation logbooks and records are estimated to be $95 \%$ accurate.

"Overall data quality is determined by multiplying the "\% Capture" and "Data Quality" columns and summing the products. 